\title{
A törmelékes üledékek és kốzetek petrográfiai vizsgálati eredményei a Kárpát-Pannon térség kutatásában: a magyar kutatók hozzájárulása az elmúlt 150 évben
}

\author{
JózSA Sándor ${ }^{1}$, SzAKMÁNy György ${ }^{1}$, MikLós Dóra Georgina ${ }^{1}$, VARGA Andrea ${ }^{2, *}$ \\ 'ELTE, Természettudományi Kar, Kőzettan-Geokémiai Tanszék, 1117 Budapest, Pázmány Péter sétány 1/C \\ ${ }^{2}$ Szegedi Tudományegyetem, TTIK Ásványtani, Geokémiai és Kőzettani Tanszék, 6722 Szeged, Egyetem u. 2. \\ "levelező szerzô, e-mail: raucsikvarga @geo.u-szeged.hu
}

\section{Petrographic results of clastic sedimentary rocks in the Carpathian-Pannonian Region: the Hungarian contribution during the past 150 years}

Abstract

\begin{abstract}
In honour of the 150-year history of the Földtani Közlöny (the Bulletin of the Hungarian Geological Society), this paper presents a historical review of petrographic studies of clastic sediments and sedimentary rocks in Hungary. The selected topics are somewhat subjective, reflecting the main research interest of the respective authors. The section on conventional petrography is organized by clast/grain size and focuses on rocks coarser than silt (i.e. sand, granules, pebbles, cobbles, and boulders). The discussion is based on respective geographic areas and their stratigraphy, with particular focus being directed towards provenance analysis. This is followed by a review of studies on sandstone diagenesis. The latter is a research field that has gained increasing importance over the last decade or so, especially in the Neogene Pannonian Basin; it has been possible to examine this basin due to the presence of exploration well-bores. Finally, results of the archaeometry of prehistoric stone tools, another developing field of research, are reviewed.
\end{abstract}

Keywords: research review, terrigenous sediments, micromineralogy, sandstone, diagenesis, archaeometry

Összefoglalás

A 150 éves évfordulóját ünneplő Földtani Közlöny tiszteletére munkánkban a törmelékes üledékes kőzetek petrográfiai vizsgálataira vonatkozó hazai tudományos eredmények összefoglaló értékelését mutatjuk be a kezdetektôl napjainkig. A szerzők kutatási területeihez igazodva, a kiválasztott főbb témakörök kutatási irányainak rövid ismertetését követően a törmelékes üledékek és kőzetek kôzetlisztnél nagyobb szemcseméretú detritális elegyrészeinek (görgeteg-kôzettömb, kavics-konglomerátum, homok-homokkő és mikroásvány vizsgálatok) leírásait tartalmazó munkákat tekintettük át területi és kor szerinti csoportosításban. A leírás ténye és a kőzetmeghatározás módszertana mellett figyelmünket a forráskőzet meghatározását és a lepusztulási terület behatárolását (eredetkutatás, provenienciaanalízis) célzó munkákra irányítottuk. Majd egy hazánkban feltörekvő irányzat, a homokkövek diagenezistörténete került terítékre, különös tekintettel a főleg mélyfúrásokkal feltárt neogén képződményekre. Végül szintén egy újabban fejlődésnek indult szakterülettel, a homokkő anyagú szerszámkövek archeometriájával kapcsolatos kutatási eredményeket mutatjuk be.

Tárgyszavak: kutatástörténet, terrigén üledékek, mikromineralógia, homokkó, diagenezis, archeometria

\section{Bevezetés — A törmelékes üledékek és kőzetek kutatási irányai}

A törmelékes üledékeket, illetve törmelékes üledékes kőzeteket sok esetben sziliciklasztitoknak is nevezik, de tudjuk, hogy a mészanyagú törmelék akár jelentős hányadát képviselheti a detritális elegyrészeknek, így az ebben a vonatkozásban kissé félrevezetô, leszúkítő értelmú sziliciklasztit kifejezést igyekszünk korlátozottan, csak a definíciójának (lásd: 1. https) megfelelő esetekben használni.

A törmelékes üledékes kőzetek képződésének négy- lépcsôs folyamatából (mállás-aprózódás, szállítás, leülepedés, kôzetté válás; 1 . ábra) jelen dolgozatban leginkább csak az első és utolsó lépcső eredményével foglalkozunk. Egyrészt azzal, hogy a vizsgált mintában milyen és honnan származó kózetek lepusztult törmelékanyaga található meg (a forráskőzet meghatározása és azonosítása, más szóval provenienciaanalízis), másrészt azzal, hogy a lepusztult törmelék végleges leülepedése után, a betemetődés során az üledékben, illetve kőzetben milyen diagenetikus folyamatok játszódhatnak le (diagenezistörténet).

Nem térünk ki az olyan, fóleg a szedimentológia tárgy- 


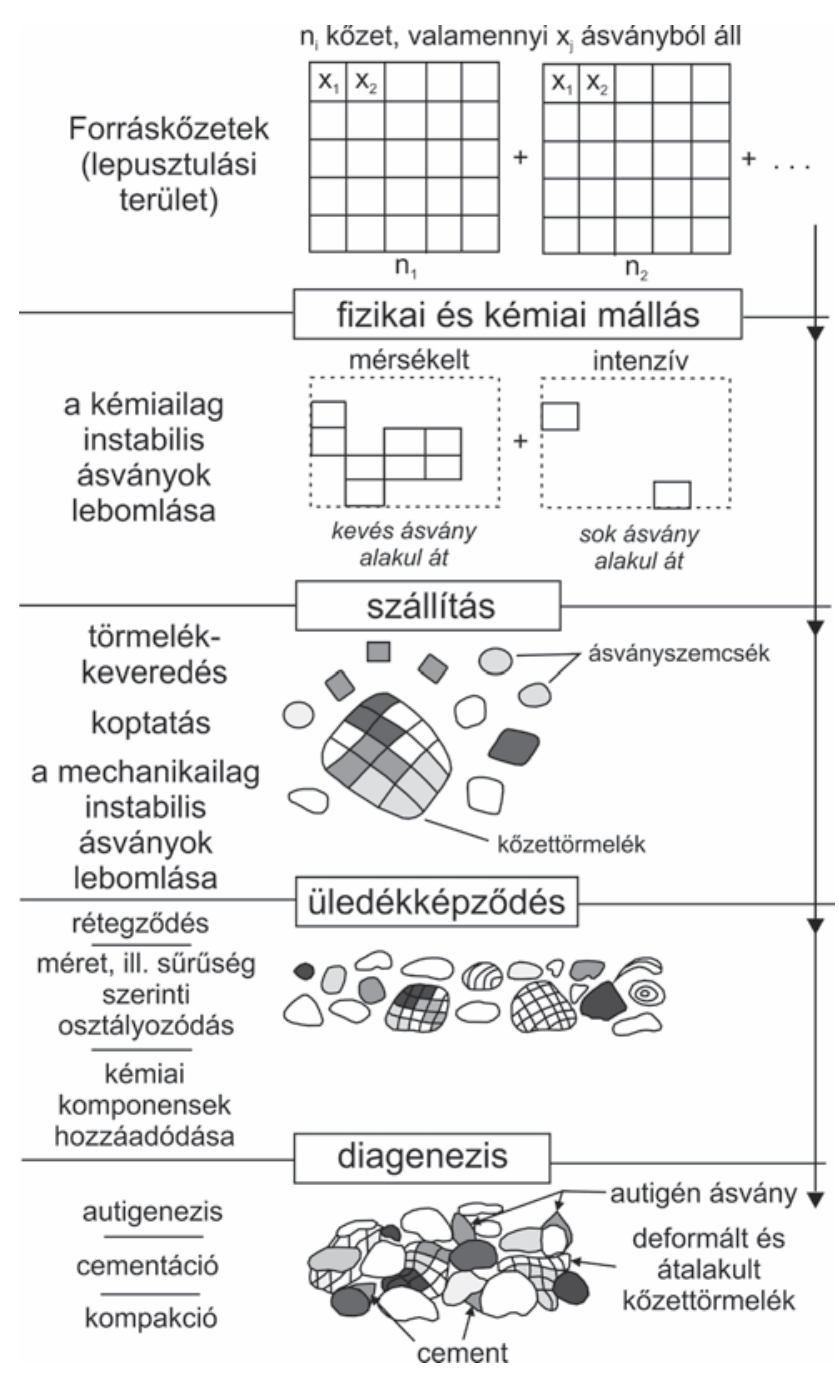

1. ábra. Homokból homokkő: az üledékes ciklus lépései (PETTıJOHN et al. 1972 alapján)

Figure 1. Transformation from sand to stone (sandstone): steps of the sedimentary cycle after PETTIJOHN et al. (1972)

körébe tartozó jelenségek hazai vizsgálati eredményeire, amelyek a törmelék szállítása és leülepedése során alakulnak ki (pl. koptatottsággal, osztályozottsággal, rétegzettséggel kapcsolatos vizsgálatok). Mivel célunk kimondottan a petrográfia módszereivel, fóleg makroszkópos és fénymikroszkópos meghatározásokkal elért eredmények bemutatása, a további lehetséges vizsgálati módszereket (SEM, OSL, kormeghatározási módszerek, izotópos mérések stb.) esetenként megemlítjük, de nem részletezzük. Ugyancsak el kellett tekintenünk többek között a törmelékes képződmények múszaki földtani (pl. építésföldtan, vízföldtan), múvészeti (pl. mútárgyak eredetvizsgálata, restaurálása) és búnügyi vonatkozású alkalmazási területein elért hazai eredmények bemutatásától. Részletes ismertetést adunk azonban a hazánkban előforduló homokkő anyagú szerszámkövek archeometriai vizsgálati eredményeiról.

Jelen írás az elmúlt 150 év hazai munkáit - különös tekintettel a Földtani Közlönyben megjelent tanulmányokra — hivatott összesíteni, de nem törekedhettünk a teljességre. A rendelkezésre álló hatalmas mennyiségú szakirodalmi adatnak csak egy része érhető el digitális formában az interneten, ezért, valamint a terjedelmi korlátok miatt az értékeléshez a legtöbb esetben nem tudtuk figyelembe venni a korlátozottan hozzáférhetô kéziratos anyagokat (pl. adattári jelentések, egyetemi terepgyakorlati jelentések, diákköri- és szakdolgozatok, $\mathrm{PhD}$ értekezések).

150 év alatt a történelem jelentős változásokat hozott Magyarországra. A magyarságot és a magyarok lakta területeket új határok szabdalták szét, a vasfüggöny mögött pedig a földtudomány kutatási lehetőségei mind anyagi, mind területi, mind szellemi vonatkozásban igen nagy mértékben tovább szúkuültek. Ez az összefoglaló, ha kényszerúen is, de tükrözi ezeket a korlátokat, ezért itt most leginkább csak a hazai kutatók trianoni határokon belüli területeken végzett kutatási eredményeinek ismertetésére szorítkozunk.

A törmelékes üledékeken és kôzeteken végzett kutatási eredmények bemutatását három fő témakörben tárgyaljuk, olyan sorrendben, ahogy a kőzettörténet folyamatai következnek egymás után. Először az üledékek és kőzetek törmelékszemcséinek (detritális elegyrészek) meghatározása és forráskőzettel, esetleg forrásterülettel való azonosítása terén elért főbb eredményeket ismertetjük. Ezt követően a homokokra, homokkövekre ható diagenetikus folyamatokra vonatkozó alapismereteket és az ezen a területen elért hazai kutatási eredményeket összesítjük. Végül az alkalmazott tudományok közül az archeometria szakterületén belül a homokkő anyagú, főleg szerszámkövekre vonatkozó hazai kutatási eredményeket mutatjuk be.

\section{Törmelékes elegyrészek petrográfiája}

A törmelékes üledékek és kőzetek lepusztulási területről származó törmelékes, más néven allotigén vagy detritális elegyrészeit többféle petrográfiai paraméterrel jellemezhetjük (méret, alak, termet, koptatottság, anyag stb.). Az itt következô tárgyalás alapjául ezek közül a szemcseméretet választottuk, mert ez a legegyszerúbben kivitelezhetô osztályozás alapja. Ezért külön alfejezetben tárgyaljuk azokat a munkákat, amelyekben a vizsgált kőzetekben található durva törmelékszemcsék anyagát szabad szemmel (makroszkóposan) és/vagy vékonycsiszolatban fénymikroszkóposan határozták meg, külön a makroszkópos és vékonycsiszolatos homokkő leírásokat tartalmazó tanulmányokat és a mikromineralógia fénymikroszkópos módszerrel elért vizsgálati eredményeit. Végül egy mindezeket összesító vizsgálatsort („,Komplex Eredetvizsgáló módszer”, KEVi; MikLós et al. 2018) mutatunk be.

\section{Durvatörmelékek vizsgálata}

A kavicsok mint csodálatos, varázslatos tárgyak mindig vonzották az embert, és még a mai világban is gyakran elbúvölnek minket. Mintha valami ôsi vonzalom éledne újra az egykor megélhetést biztosító értékes lelet iránt (pl. FARKAS-SzŐKE 2008). A földtudósokat viszont inkább a kavicsokban rejlő megannyi, térben és időben távolra 
mutató információ megszerzésének lehetősége vonzza. Akár olyanoké is, amelyeket a kavics származási helyéről már nem lehet megszerezni.

A durvatörmelékek (szögletes törmelékek, koptatott törmelékek: kavicsok, továbbá nagyobb méretú hömpölyök, kőtuskók, görgetegek, kőzettömbök) tudományos jellegú megfigyelése és leírása már az 1800-as évek közepétől a geológiai kutatómunka egyik kedvelt ágának számított. Sok esetben akkor még csak terepi módszereket alkalmaztak, és csak a kavicsok által képviselt kőzetfajták neveinek felsorolására szorítkoztak (BöcKH 1872, HoFMANN 1879, RоTH 1879, PAPP 1899). Az esetek egy részében azonban széleskörú terepi kőzetismereteiknek köszönhetően — azt is megállapították, hogy milyen ismert kőzetformációból vagy mely területekről származhat egy-egy kavics vagy hömpöly anyaga (pl. SzABÓ 1872, Косн 1874, Rотн 1885, SZÁDECZKY 1932). Egy-egy különleges, fontosnak vélt kavicsleletről, mint pl. a „Buda-Kovácsi hegység eocän conglomerat trachytnemú eruptív kőzet töredékei"-ről (HoFMANN 1871) részletes és élvezetes makroszkópos, sôt úttörő jelleggel „górcsői” kôzetleírást is olvashatunk. Ez utóbbi esetben például több mint 100 évvel később HORVÁTH \& TARI (1987) geokémiai vizsgálatokkal, FARICS et al. (2015) részletes petrográfiai vizsgálatokkal pontosították a korábbi eredményeket, és a vulkanitkavicsokat egy közeli triász vulkáni előfordulás termékeiből származtatták.

Az elmúlt 150 év során szinte minden korszak neves kutatója készített leírásokat a különböző magyarországi durvatörmelékes összletek kavicsairól, kőzettömbjeiről. A Mecseki perm-triász törmelékes rétegsor kavicsanyagának összetétele alapján például megállapították, hogy az akkori háttérterület főleg kristályos és savanyú vulkáni kőzetekből állt, és hogy ezek aránya térben és időben is határozott változékonyságot mutatott (VADÁSZ 1935, BARABÁSNÉ STUHL 1981, FAZEKAS 1987 és hivatkozásai, VARGA et al. 2007, Bodor \& SZAKMÁNy 2009, Bodor et al. 2012). A nyugati-mecseki jura rétegsor is tartalmazott érdekes törmelékes betelepüléseket. Az alsó-jura Vasasi Márga kavics és breccsa betelepüléseiben közeli déli területekről származó késő-triász karbonátkőzet- és telepeskoralltöredékeket, és az akkor kis területen még délebbre kibukkanó metamorf aljzatból származtatható kisszámú kvarc- és kőzettörmeléket mutattak ki (CSÁsZÁr 2006, CsÁSZÁr et al. 2007).

A mecseki alsó-miocén durvatörmelékes összlet kavicsanyaga ennél sokkal változatosabb képet mutatott (VÉGH 1956, JÁMBOR \& SZABÓ 1961, HÁMOR 1970, RAVASZNÉ BARANYAI 1973, VARGA et al. 2002, JózSA et al. 2009 és hivatkozásai, MAGYAR et al. 2016). A Nyugati-Mecsekben ebből kerültek elő többek között felsô-karbon növénymaradványos szenes agyagkő kavicsok (Soós \& JÁMBOR 1960, WÉBER 1964, BARBACKA et al. 1997, PHILIPPE et al. 2000, GuLYÁs-KIS 2003), szintén felső-karbon szürke, valamint permi vörös homokkő kavicsok (pl. VARGA et al. 2001, 2003), a korábban topázgránitnak leírt andaluzitos gránitkavicsok (SZAKMÁNY \& JóZSA 1994), egy eklogitkavics (HoRVÁtH et al. 2003) és két egyedülállóan ritka eocén kalkrétkavics, amelyhez hasonló korú és típusú kőzet korábban nem volt ismert a Mecsekben (VARGA et al. 2002). A Soós \& JÁMBOR (1960) által először leírt felső-karbon, változatos szemcseméretú, szenes törmelékes kőzetanyagú kavicsok forráskőzetét a kavicsvizsgálataik alapján előre jelzett területen késóbb mélyült kutatófúrásokban meg is találták (JÁMBOR 1969). A Keleti-Mecsekben alsó-kréta magmatit- és szkarnkavicsok (HoRVÁTH 1988) és az ezekhez kapcsolható óriási, általában több tíz cm-es, de akár az egy méter átmérôt is elérő magnetithömpölyök (SzABÓ 1872, VADÁSZ 1940, SZTRÓKAY 1952) váltak ismertté a miocén törmelékes összletből.

A Dunántúli-középhegység törmelékes képződményeinek kavicsösszetételét a karbontól (Fülei Konglomerátum) a pleisztocénig JÁMBOR \& KORPÁs (1971), az oligocéntől a miocénig KORPÁs (1981) tárgyalták átfogóan és részletesen. Ezek közül a Balaton-felvidéki vörös homokkő összlet riolit anyagú kavicsait JUHÁSZ (1962) részletes mikroszkópos petrográfiai vizsgálatnak vetette alá, és a mecseki permi homokkövek hasonló anyagú kavicsaival rokon összetételúnek találta. A Bakony törmelékes kőzetei többnyire helyi származású kavicsokat tartalmaznak, de a felső-eocén tengerparti konglomerátumban már kis- és közepes fokú metamorfit kavicsok is megjelennek (pl. VARRÓK 1954). A nagy területen feltárt oligocén folyóvízi, polimikt Csatkai Formáció Rendeki-hegy fennsíkján fellelhető hömpölyei akár a $45 \mathrm{~cm}$ átmérôt is elérhetik, anyaguk zömmel egzotikus. HAAS (1984) szerint mintegy 30 km-rôl származhatnak egy mára már eltemetett, délre elhelyezkedő forrásterületről. BENEDEK et al. (2001) az andezitkavicsok vizsgálatából kiindulva modern geokémiai és geokronológiai (hasadványnyomokon alapuló) módszerekkel a Csatkai kavicsösszlet számos lehetséges forrásterületét azonosították a Periadriai-öv mentén egészen a Déli-Alpokig. Az oligocén tengerparti Hárshegyi Homokkő kavicsainak zöme kvarc és kvarcit, de a kisszámú metamorf kavics alapján északi, vepori eredetet valószínúsítettek (FEKETE 1935, KASZANITZKY 1956, BÁLDI et al. 1976). SZTANÓ (1990) a gerecsei alsó-kréta csatornakitöltő Köszörúkőbányai Konglomerátumban az uralkodóan intraformációs kőzetek, valamint mészkő és tüzkő mellett kevés, vékonycsiszolatosan is azonosított metamorfitot és vulkanitot említ. ORAVECZ (1965) szilur ősmaradványokat (pl. Hystrichosphaerida) mutatott ki néhány permtôl pleisztocénig terjedô korú törmelékes összlet kovapala kavicsaiban, amit az egyik geológusnóta meg is örökített (szerző: PAPP G., lásd: 2. https).

Az ország keleti részén feltárt egykori tengerparti durvatörmelékes összletekben zömmel rövid szállítást szenvedett, helyi lepusztulási területről származó, változatos kőzetanyagú kavicsokat találhatunk. Ilyen például az Upponyi-hegység déli részén feltáruló kréta időszaki Nekézsenyi Konglomerátum (BREZSNYÁNSZKY \& HAAS 1984), a Rudabányai-hegység délkeleti peremén megjelenô felső-oligocén Szuhogyi Konglomerátum (SzENTPÉTERY 1988, Bodrogi \& Szentpétery 2000) és a Darnó-hegy nyugati szélén megjelenő alsó-miocén Darnói Konglomerátum (KISS 1958, SZTANÓ \& JÓZSA 1996). 
A legnagyobb tömegú, változatos összetételû durvatörmeléket azonban a pleisztocén jégkorszakoknak köszönhetjük (pl. SzÁDECZKY 1932, SzUJó et al. 2017). Mai folyóink meder- és teraszanyaga ezért már legalább 150 éve (pl. Koch 1874) kedvelt kutatási téma (az ősember tevékenységéról nem is beszélve, pl. HoRvÁTH 2013). Folyóink közül talán a Duna kavicsanyaga a legváltozatosabb (2. ábra), a helyi áthalmozásokon kívül a legkülönbözőbb alpi, kárpáti és cseh-masszívumi területekról származik (pl. BÓDI 1938, SZÁDECZKY-KARDOSS 1939, SÁSDI 2003, SZEBERÉNYI et al. 2015); a ritka vagy különleges leletek közül azonban csak az eklogitkavicsokról született eddig nyomtatott közlemény (HoRváTH et al. 2005). Még érdekesebbek a Duna fiatal teraszüledékeiből rendre előbukkanó, talányos módon idekerült, akár méteres nagyságot is elérô, sok esetben teljesen szögletes egzotikus hömpölyök, kôtömbök, „kőtuskók” (pl. KRIVÁN 1973, ZSEMLE et al. 2001). Kutatásuk történetét JÁMBOR (2010) foglalta össze, de néhány különleges, ritka kőzetpéldány (dumortierites gneisz, klinohumitos márvány és szkapolitos amfibolit) pontos forrását (Spitz környéke, Cseh-masszívum déli része, Ausztria) és több száz km-es szállítási módját (potamopagetolitok, azaz tutajkövek; 2. ábra $a$ és $d$ ) SPRÁNITZ et al. (2017) ásványkőzettani összehasonlító vizsgálatai tisztázták megnyugtatóan (3. ábra). Érdekesség az is, hogy a tátrai morénaüledékek törmelékanyagának korai vizsgálata (Rотн 1885) mellett SzABÓ (1872) mátrai morénaüledékról is tudósított.

A kavicsok észleléseit már kezdetektől fogva koptatottsági és felszínmorfológiai (kopásnyomok) megfigyelésekkel egészítették ki (pl. HoFMANN 1871). Az alaktani megfigyelések és mérések különösen a SZÁDECZKY-KARDOSS (1933) által kidolgozott, nemzetközileg is elismert és mai
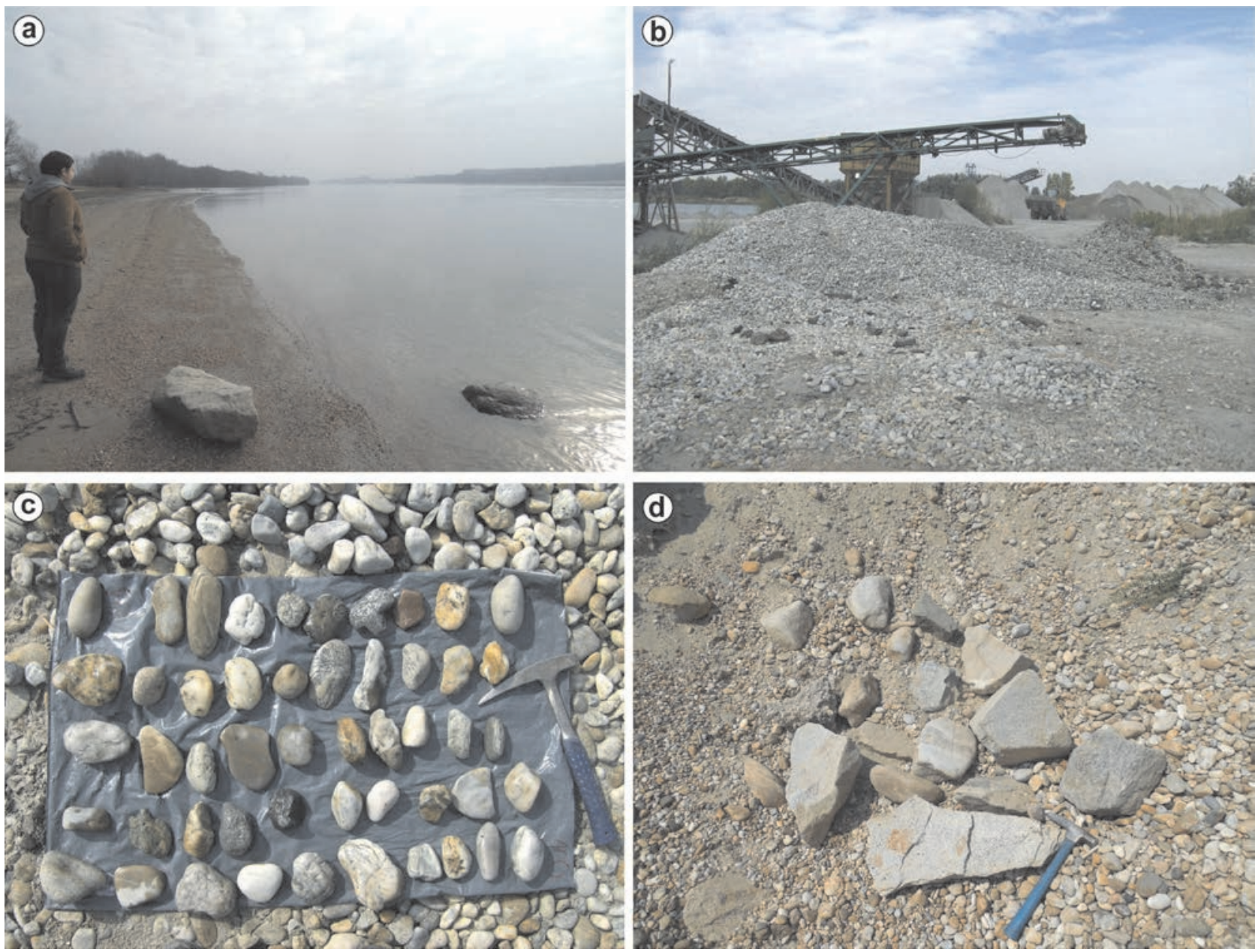

2. ábra. „Dunakavicsok”

a) A Duna pleisztocén teraszanyagából kimosódott nagy méretủ, gyengén koptatott kőzettömbök (potamopagetolitok, azaz folyami tutajkövek) a Solt melletti Duna-parton; b) A Duna fiatal teraszanyagát kitermelő győrzámolyi kavicsbánya látképe. A frissen kirostált durva kavics (kulé) uszadékfákat (sötétbarna darabok), emlőscsontokat és nagyobb szögletes kőzetdarabokat akár nagyobb mennyiségben is tartalmazhat; c) Terepi kavicsvizsgálat (jellemzés, meghatározás, számlálás) előkészülete az egyik Győr melletti kavicsbányában; d) Zömmel szögletes, kristályos kőzetanyagú (gránit, kvarcit, amfibolit) folyami tutajkövek (potamopagetolitok) egy Győr melletti kavicsbányában

Figure 2. Pebbles and boulders from the Danube

a) Large, angular fluvial dropstone boulders (potamopagetolite) on the river bank of Danube near Solt, washed out from the Pleistocene terrace material; b) Young terrace material of Danube is exploited in the gravel pit of Győrzámoly. Screened out coarse cobble fraction often contains large amount of drift-wood (dark brown pieces), bones of mammals and angular boulders; c) Preparing for field examination of pebbles (characterization, determination, counting) in a gravel pit near Györ; d) Mostly angular fluvial dropstones (potamopagetolites) consisting of crystalline rocks (granite, quartzite, amphibolite) in a gravel pit near Győr 

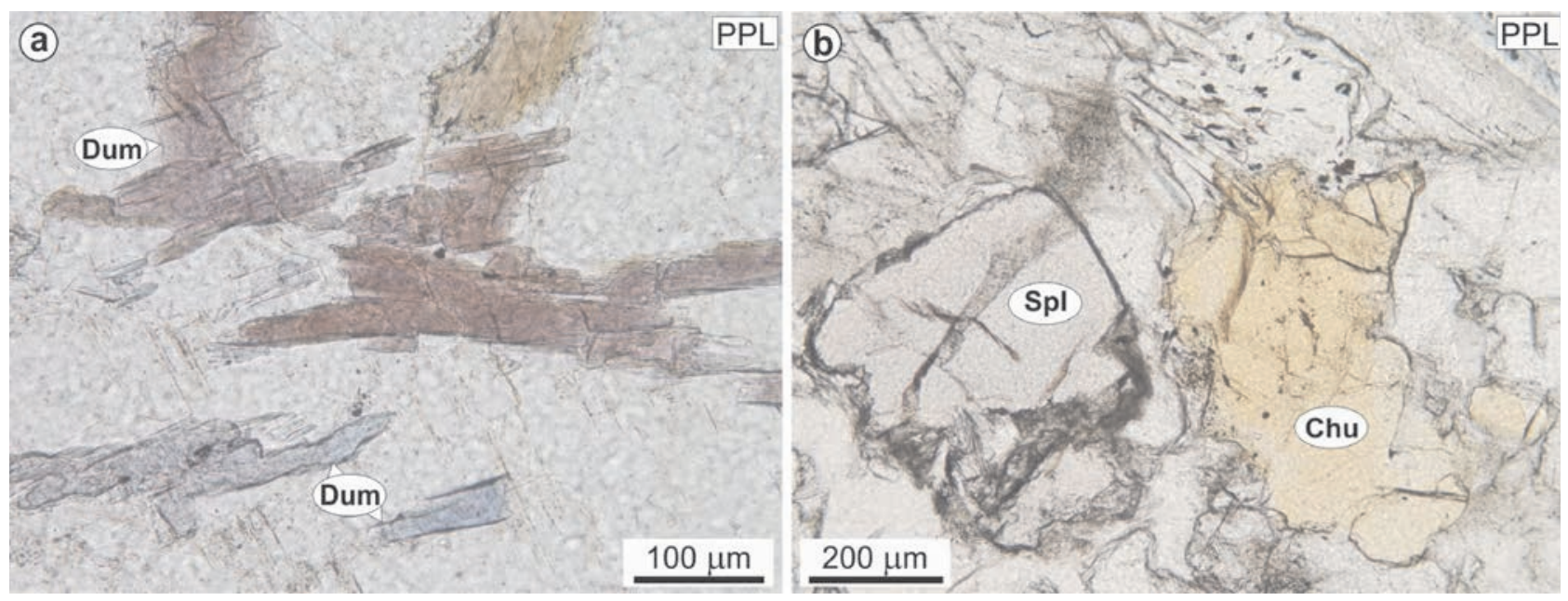

3. ábra. A dunai folyami durvatörmelékből származó különleges kőzettípusok mikroszkópi megjelenése (Dunavarsány, kavicsbánya, Aqua Kft.). a) Rózsaszín-kék pleokroizmust mutató dumortierit (Dum) halmaz gneisz kavicsban; b) Négyszögletes spinell (Spl) szemcse és okkersárga klinohumit (Chu) polarizációs mikroszkópi fényképe mintegy $80 \mathrm{~cm}$ átmérőjü, közepesen koptatott kontakt dolomárvány anyagú folyami tutajkőből. PPL = egy nikolos fotó

Figure 3. Photomicrographs of special rock types from Danubian boulders (Dunavarsány, gravel pit of Aqua Ltd.). a) Dumortierite (Dum) grains with pink-blue pleocroism from a gneiss pebble; b) Square shaped spinel (Spl) grain and yellow clinohumite (Chu) in a medium rounded contact dolomarble fluvial dropstone boulder (d=80 cm). $P P L=$ Plane Polarized Light

napig használt vizsgálati módszer (CPV-módszer) megszületése után szaporodtak meg. Kezdetben csak a laza, pannóniai-pleisztocén hordalékok (BóDI 1938; STRAUSZ 1949, 1952; PÉCSINÉ DonÁth 1958), később már az idősebb, cementált konglomerátumok (VÉGH 1956: HidasVáralja; KASZANITZKY 1956: Hárshegyi Homokkő; GYŐRFI 2015: Dráva-medence) kavicsainak CPV értékeit is kiszámolták szállítási viszonyaik meghatározása vagy akár teraszok azonosítása céljából. A szél, vagy ritka esetben a jég csiszoló hatására kialakult formai és felületi jegyeket mutató kavicsok (éles kavics, fényes kavics, szél- és jégbarázdás kavics) megfigyelése és leírása is viszonylag gazdag hazai szakirodalommal rendelkezik (pl. JÁMBOR 1992, 2002 és hivatkozásai; CsILlag et al. 2010; THAMÓNÉ Bozsó et al. 2012; T. BIRó et al. 2013). Folyóparti kavicsok ihlették a világraszóló „Gömböc” megalkotását egy teljesen új kavicsmorfológiai vizsgálati módszer kidolgozásán keresztül (SzABó \& Domokos 2010, Doмокоs 2019 és hivatkozásai). Az új osztályozás alapja egy kód, amelyet a kavicsok lehetséges egyensúlyi helyzeteinek (fekvő egyensúlyi pont $=$ lappont, billegố egyensúlyi pont $=$ nyeregpont, ingó egyensúlyi pont = csúcspont) száma alapján határoznak meg.

A kavicsok szintén jelentős szerepet játszanak a barlangok képződésében és a barlangi üledékek összetételében (GYURICZA \& SÁSDI 2009), sôt kavicsrétegekben kialakult barlangok is ismertek (pl. Tata környékén; pl. ALMÁDY 1988). A barlangkutatók legtöbbször általában csak a barlangi kavicskitöltés tényét és főbb kavicstípusait (pl. mészkő, kvarckavics) rögzítették (pl. Erdélyi-khg.: KESSZLER 1942; Béke-barlang: JAKUCS 1953; Baradla: BARÁTOSI 1961, KoRDOS 1976, VID 2012). Akadnak azonban olyan leírások is, amelyekben a barlangi kavicsok forráskőzetét vagy lehetséges származási területét is meghatározták. Tata tóvárosi Angolkert forrásbarlangjaiban pannóniai kavicsanyagot, köztük mikrokristályos kovakő változatokat (karneol, jáspis, kalcedon) írtak le (ALMÁdY 1988). A Budai Várbarlang kavicsanyagáról megállapították, hogy az nem Duna-terasz eredetú, hanem zömmel a Budai-hegységben is megtalálható, az Ördögárok vízgyújtő területéről származtatott triász időszaki mészkő, illetve Hárshegyi Homokkó anyagú (LEÉL-Ôsssy 2011 és hivatkozásai). A Baradla kavicsanyaga zömmel a pleisztocén Borsodi Kavicsból származik, amelyben a Szepes-Gömöri-érchegység kisfokú metaüledékes kőzetei (kvarcit, metahomokkő és fillit változatok) uralkodnak (BERÉNYI ÜVEGES et al. 2006, VID 2007, POLACSEK \& BA 2017).

A fenti áttekintés számos kiemelkedő eredményre felhívta a figyelmet, azonban a kavicsok eredetkutatása még napjainkban is adhat munkát a geológusoknak. Számos kavicsfajta forrása máig ismeretlen (pl. nummuliteszes tûzkő: MARKó \& KÁZMÉR 2004, andaluzitos gránit: JózSA et al. 2009).

\section{Homokkövek petrográfiai elemzése}

A törmelékes üledékes kőzetek legnagyobb tömegben, legtöbb területen felhasználható változata a homokkő, így nemcsak csodálatos természetes sziklaképződményekben (pl. a Babás Szerkövek a Jakab-hegyen, a Mecsekben vagy a Nagy-kő Bükkszenterzsébeten), hanem mára már jórészt felhagyott kőbányákban is találkozhatunk vele (pl. az Alsóörsi Amfiteátrum).

A homokkő lényeges allotigén elegyrészei (ebben a fejezetben csak ezekre összpontosítunk) viszonylag kis, 2 $\mathrm{mm}$ alatti szemcseméretük miatt szabad szemmel nehezen határozhatók meg, az általában jóval kisebb méretben megjelenő, de a forráskőzet meghatározása szempontjából 
informatívabb akcesszórikus ásványok pedig szabad szemmel láthatatlanok. Ezért lett a homokok és homokkövek forrásmeghatározásának egyik módszere a mikromineralógia (lásd a Mikromineralógia c. fejezetet). Mivel a homokkő rétegsorok legtöbbször kavicsot is tartalmaznak — akár szórványosan, akár vastag konglomerátumrétegek formájában — a homokkövek forrásmeghatározása a velük együtt megjelenô, könnyebben meghatározható kavicsok vizsgálatával is megvalósulhat. Így aztán a homokköveket a földtani munkák viszonylag hosszú időn át inkább csak megemlítették, már csak azért is, mert rétegtani besorolásukhoz ősmaradvány-tartalmuk megismerésére nagyobb szükség volt (pl. KocH 1871, NosZKY 1935). Ennek ellenére számos esetben a földtani munkák is tartalmaztak részletes terepi makroszkópos leírást (pl. CsÁszÁR 1995, valamint a Durvatörmelékek vizsgálata és a Mikromineralógia c. fejezetek idevágó hivatkozásai). A kőzettani beállítottságú kutatók viszont korábban a kristályos kőzetekkel foglalkoztak szívesebben (talán ma sincs ez másképp), ezért a homokkövek kôzettani összetételének részletes feldolgozása háttérbe szorult.

A kifinomultabb homokkő petrográfia a polarizációs mikroszkóp elterjedésével és általános használatával kezdett kiteljesedni, de komolyan közrejátszott ebben az olajipar térnyerése is, hiszen mint kiváló tárolókőzetek, megismerésük gazdasági érdekeket is szolgál. Ebból a szempontból fontosabb volt a porozitással összefüggő folyamatok megismerése (lásd a Homokkövek diagenezise c. fejezetet), de ezáltal más kőzettani tulajdonságok kutatása is lendületet kapott. A homokkőben lévő törmelékszemcséket különböző kategóriákba sorolták (pl. kvarc: Q, földpátok: F, kőzettörmelékek: R vagy L, mátrix), mennyiségüket polarizációs mikroszkópban kimérték, és százalékos megoszlásukat háromszögdiagramokon ábrázolták (4. ábra, Q-F-R-diagram: petrográfiai osztályozás, FoLK 1956, Pettijohn et al. 1972; Q-F-L és kapcsolódó diagramok: forrásterület-analízis, DiCKINSON 1970, DiCKINSON

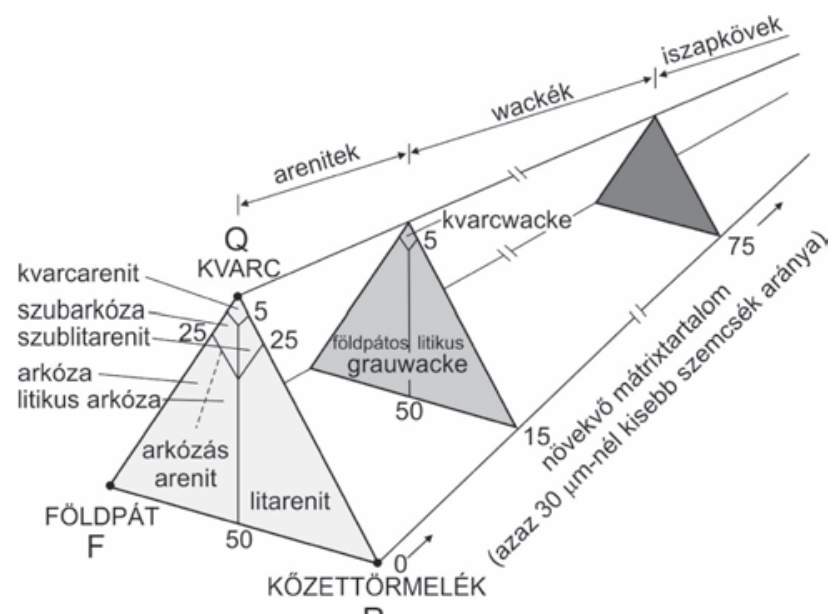

$\mathrm{R}$

4. ábra. A homokkövek petrográfiai osztályozása (PeTtıoHN et al. 1972 alapján)

Figure 4. Petrographic classification of sandstones after PETTIJOHN et al. (1972)
\& SuCZEK 1979). A homokkövek pontos elnevezéséhez és származási területük minősítéséhez ezek a rendszerezések széles körben elterjedtek (pl. PETTIJOHN 1954; FOLK 1956; DiCKINSON 1970, 1985; PETTIJOHN et al. 1972; DiCKINSON \& SUCZEK 1979; INGERSOLL 1990).

Hazánk petrográfiailag legrészletesebben vizsgált homokkövei a Mecsek-Villányi térség felsốkarbon-triász rétegsorának tagjai. Az 1950-es évek végétől folyamatosan zajló intenzív kőzettani kutatások eredményeit ismertetô kéziratok (pl. Mecseki Ércbányászati Vállalat, uránérckutatás) megszületését követően először FAzEKAS (1987) adott átfogó, részletes kavics és homokkő összetételi leírást a Korpádi, a Cserdi, a Kővágószőlősi és a Jakabhegyi Formációkról. Elsőként adta meg a vizsgált homokkövek akkori modern PeTTIJOHN et al. (1972) szerinti kőzettani besorolását, rávilágítva a módszer néhány hiányosságára is. Megfigyelte a kristályos alaphegységből származó törmelékek arányainak időbeli változását (metamorfitok és vulkanitok, majd a felső-permben gránitok is) és egyes vulkanitok északnyugat felőli behordási irányát. Később ennek a rétegsornak szinte minden formációjáról igen részletes petrográfiai elemzés készült, amelynek segítségével a lepusztulási terület kőzettani összetételét és egyes homokkövek háttérterületének lemeztektonikai helyzetét is pontosították (Tésenyi Homokkő: VARGA et al. 2001, 2003; Bodai Agyagkő: VARGA et al. 2006; Túronyi Formáció: VARGA et al. 2008; Korpádi Homokkő: VARGA et al. 2004, 2014; Jakabhegyi Homokkő: FAZEKAS 1989, Csicsák \& SZAKMÁNY 1998).

A ma is használatos, akkor még újnak számító, GazziDickinson néven ismert szemcseelemző módszert (DICKINSON 1970, 1985; DiCKINSON \& SUCZEK, 1979; ZuFFA 1980 stb.) a gerecsei kréta törmelékes kőzetek vizsgálatával ÁRGYELÁN $(1989,1995)$ vezette be Magyarországon. Eredményeit további részletes petrográfiai és mikromineralógiai megfigyelésekkel egészítette ki (lásd a Mikromineralógia fejezetet). Megállapította, hogy „a törmelékek óceáni szigetívrôl, óceáni szutúra zónához kapcsolódó ofiolitokból és mélytengeri képződményekből, valamint az áttolódott, felgyúrt öv kontinentális kéregrészeiből származhatnak".

A kainozoos összletek közül a Hárshegyi Homokkőről kezdetben inkább csak terepi, kőbányászati szempontú leírások születtek (КоCH 1871). Ugyan részletes mikroszkópi kőzetleírás máig nem készült, kovásodását és hidrotermás érkitöltéseit azonban késóbb többen is tanulmányozták (FEKETE 1935, BÁLDI \& NAGYMAROSI 1976, GÁL et al. 2008).

Egyik legnagyobb kiterjedésú homokkő előfordulásunk a glaukonit tartalmáról ismert észak-magyarországi alsómiocén Pétervásárai Homokkő. Első részletesebb polarizációs mikroszkópi vizsgálatát SzTANó \& JózSA (1996) közölték (megállapításaikat lásd a Mikromineralógia fejezetben). Szőcs et al. (2015) a homokkô törmelékanyagának ismertetése mellett inkább a diagenezistörténetre összpontosítottak (lásd a Homokkövek diagenezise fejezetet).

Érdemes megemlíteni, hogy egyes rétegsorokban 
korábban tufarétegként leírt képződmények valójában kisebb-nagyobb mértékben áthalmozott vulkáni eredetú törmelékanyagban gazdag vulkanoklasztitok, vulkanogén homokok, homokkövek. Ennek egyik példája a Mátyáshegyi-barlangban és környékén a felszínen is megtalálható, a felső-eocén bryozoás márgába települő, főleg vulkáni eredetú kvarcot, savanyúvulkanit-szemcséket és horzsakövet tartalmazó vulkanogén homokkő (BIRÓ et al. 2013 és hivatkozásai). A Keleti-Bakony középső triász (ladin) tufás képződményeinek (GYALOG \& BUDAI 2004) részletes petrográfiai leírásával és földtani értelmezésével FARICS \& JózSA (2017) foglalkoztak.

Polarizációs mikroszkópi vizsgálatok további homokkó kifejlődésekről is készültek. THAMÓ-Bozsó (1993) a Pannon-medence eocén-kvarter homokköveinek és homokjainak érettségi indexét és kőzettani besorolását MCBRIDGE (1963) szerint állapította meg. BÉRCZI \& VICZIÁN (1973) pedig a dél-alföldi terület neogén törmelékes kőzeteit ásványos összetételük alapján nevezték el, és kisfokú metamorfitos összetételú lehordási területet állapítottak meg. Több más munkában viszont a hangsúly nem a forráskőzet meghatározásán volt, hanem az adott homokkővel kapcsolatos lehetséges gazdasági vonatkozások álltak a középpontban. Ilyenek például a törmelékes üledékes kőzetbe beáramló $\mathrm{CO}_{2}$ kôzetre gyakorolt lehetséges hatásaival kapcsolatos tanulmányok (SENDULA 2015, KIRÁLY et al. 2019), illetve a bükki permi Szentléleki Formációban kimutatott ércindikációt vizsgáló tanulmány (SZABÓ \& VINCE 2002).

\section{Mikromineralógia}

A mikromineralógia tárgyát képező kb. 0,06-0,25 mmes szemcsék lehetnek ásványszemcsék, kőzetdarabok, egykori élő szervezetek ép vagy töredékes maradványai (pl. ősmaradványok), de akár mesterséges anyagok is. Méretük a vizsgálandó kőzetben lehet eleve kicsi, de a mintaelőkészítési folyamatok (pl. törés, szitálás) során az eredetileg nagy kristályok is aprítékként kerülnek az adott mérettartományú részlegbe. A mikroásványokon belül a $2,9 \mathrm{~g} / \mathrm{cm}^{3}$-nél nagyobb sưrúségú nehézásványok általában jóval kisebb mennyiségben (néhány \%-ban) jelennek meg, mint a könynyúek, de nagyobb jelzésértékük miatt a forráskőzet azonosításában sokkal komolyabb szerepet kapnak. Hazai történetüket legutóbb THAMónÉ Bozsó (2002a) foglalta össze röviden.

A mikromineralógiai — vagy ahogy Erdélyben, sôt még inkább Székelyföldön nevezik, a parányásványtani — vizsgálatok Magyarországon az 1900-as években indultak meg. Akkor még csak a laza, finomszemcsés (szubmikroszkópos szemcseméretû) anyagokban (talaj, lösz, agyag, homok) rejtőző apró ásványszemcsék megismerése volt a célja (pl. SCHAFARZIK 1901; VENDL 1913, 1932; INKEY 1914; LENGYEL 1930, 1931). A finomszemcsés laza üledékek tudományos célú kutatása a mai napig folyamatosan zajlik és módszereiben fejlődik (pl. BIDLÓ \& TÖRÖK 1963, GEDEONNÉ RAJETZKy 1973b, PÉCSI-DonÁTH 1985, Bidló 1996, Hum 2002, BALOG et al. 2013), ipari alkalmazása is széleskörú (pl. tengerparti torlatkutatás, GonCALVES \& BRAGA 2019; olajipar). A korai hazai munkák legfőképpen a mezőgazdaság sikerességét kívánták geológiai ismeretekkel elősegíteni. Erre SzABÓ $(1858,1861)$ — úttörố módon — több talajvizsgálattal és térképezéssel foglalkozó múvében is felhívta a figyelmet. Meg volt ugyanis győződve arról, hogy a talajok rendszeres elemzése a mezógazdaság érdekeit szolgálja (INKEY 1914). A mezőgazdasági célú mikroásvány-vizsgálatok egyik fő célja volt — a teljeskörú összetétel meghatározása mellett - a talajok származásának, azaz a talajképző kôzetnek a megismerése (pl. STEFANOVITS 1952; KISS 1958; SZENDREI 1970, 1994; BIDLÓ 1996; KALMÁr et al. 1997; KUTI et al. 2003; BALOG et al. 2013). Valamivel később, a környezeti szemlélet felerôsödésével a hasznos vagy toxikus elemek kibocsájtásában és megkötésében szerepet játszó talajalkotó mikroásványok vizsgálata is fontos kutatási iránnyá vált (pl. ZENTAY 1989).

A mikromineralógia tárgya a kezdetek óta mit sem változott, de a vizsgálat alá vont, mikroszemcséket szolgáltató anyagok köre mára jelentősen kiszélesedett, néhány esetben önálló kutatási ággá fejlődött. Az egyik legfontosabb és kiterjedt hazai kutatási irány a löszök mikroásványtani vizsgálata, a munkák elsősorban a lösz lehetséges forrásterületeinek megismerését célozták meg (pl. Molnár 1961, FranYó 1963, PÉCSI-DonÁTH 1985, HorvátH et al. 1992, Hum 2002). A legújabb, átfogó értékelés szerint (THAmó-Bozsó et al. 2014) a hazai idős és fiatal löszök nagy része gránátban gazdag, finomszemcsés homok frakciójuk foóleg a Dunántúl folyóinak metamorf ásványokban gazdag ártéri homokanyagából és különbözô kainozoos törmelékes üledékekből származik. A dél-dunántúli löszök biotitban és turmalinban gazdag nehézásvány-együttese granitoid forrásra, az észak-magyarországi löszök piroxénben gazdag nehézásványai közeli vulkáni forrásra utalnak. A Kárpátmedence, azon belül is főleg a Nagyalföld pleisztocén és recens folyóvízi meder, ártéri és teraszüledékeinek, valamint szélfújta homokos üledékeinek eredetét is sokan a mikroásványok segítségével kutatták (LENGYEL 1930, 1931; SZABÓ 1955; FRANYÓ 1963; MOLNÁR 1963, 1964, 1966; GedeONNÉ RAJETZKY 1973a, b, 1976; EleK 1982, 1987; POLGÁRI 1982; KALMÁR et al. 1997; CSAPÓ 1998; BuRJÁN 2003; NÁdor et al. 2007a, b; ThAMÓ-Bozsó \& Ó. KovÁcs 2007; ThAmó-Bozsó et al. 2007 stb.). Munkáik alapján általánosságban megállapítható, hogy egyes nehézásványok jelenléte vagy dúsulása jól körülhatárolható forrásterületet jelez (pl. barna amfibol = Erdélyi-középhegység, piroxének = Északi-középhegység, glaukonit = Pétervásárai Homokkő, kékamfibol = Szepes-Gömöri-érchegység, klorit = Felső-Tiszavidék stb.). A barlangi üledékek nehézásványvizsgálatának is elsősorban a forráskőzet és származási terület megismerése volt a fó célja (pl. SzENTES 1963; FARKAS \& JÓZSA 2005, Pisznice; VID 2007, Baradla). PIROS \& GYURICZA (1986) például a Baradla hordalékában talált biotit-, hipersztén- és augitszemcséket a Sajó menti piroxénandezit piroklasztitokból származtatták.

A Magyar Állami Földtani Intézetben (MÁFI) az 1980as évektől kezdve országos programként a nehézásványokat 
érckutatás céljából is vizsgálták. HARTIKAINEN et al. (1992) a Tokaji-hegység $800 \mathrm{~km}^{2}$-es területének 207 cellájából talaj és kôzetminták mellett — patakhordalékból vett minták nehézásványrészlegét is kémiai elemzésnek vetették alá. A kapott elemzési adatok statisztikus értékelésével aranyérckutatásra perspektivikus területeket tudtak kijelölni. Egy másik, máig befejezetlen „Torlatprogram” keretében Magyarország valamennyi jelentős vízfolyásából medermintát vettek (kb. 1000 minta), és különböző könnyú, nehéz és mágneses frakciókra választották szét (FÜGEDI et al. 2015 és hivatkozásai), többek között különböző ércásvány-, különösen termésarany szemcsék dúsulásában reménykedve. A téma fontosságát jelzi, hogy a muraközi és dunai mosott aranyat már RÁKóczy (1905) a Tauern aranyteléreivel veti össze és onnan származtatja. Az 1930-as években, részben a híres aranybányáink (pl. Körmöcbánya, Nagybánya) trianoni diktátumból fakadó elvesztése miatt, átfogó torlatarany kutatás indult a Duna mentén, amelyet a Magyar Nemzeti Bank és a Pénzügyminisztérium végeztetett (PANTó 1935).

A felszíni és mélyfúrással feltárt pannóniai üledékes rétegsorok nehézásvány-vizsgálata a tudományos megközelítés mellett (HERRMANn 1954a, 1955, 1956a, b; KLEB 1968; THAMÓNÉ Bozsó 2002b) ipari jelentôségük (üveghomok: BÁRDOSSY 1958; HAJós 1954; szénhidrogén-kutatás: HERRMANN 1954b; BÉRCZI 1969; ThAMÓNÉ BozSÓ et al. 2006; vízföldtan MoLNÁR 1973; torlatkutatás) miatt vált kiemelkedő fontosságúvá. A homokbányászatban a nehézásványok elkülönítendő szennyezőnek, szerencsés esetekben hasznosítható mellékterméknek számítottak (pl. THAMÓNÉ Bozsó 1985). A szénhidrogének kutatásában a nehézásványok a medenceüledékek behordási irányainak, távolságának és lepusztulási területének meghatározásában játszottak szerepet. A magyarországi kainozoos homokok átfogó összesítő értékelését SALLAY \& THAMÓNÉ Bozsó (1988) és THAMÓNÉ Bozsó (1991) állították össze. Későbbi összefoglaló munkájukban JuHÁsz \& THAMÓNÉ Bozsó (2006) 860 felsố-miocén-pliocén (pannóniai) minta nehézásvány-adatainak értékelésével kimutatták, hogy a Pannon-medence belseje felé a szállítási távolsággal egyre uralkodóbbá válik a klorit mennyisége. Északnyugatról több közepes és nagyfokú metamorfitból származó ásvány, északkeletről több belső-kárpáti vulkáni vonulatból származtatható ásvány, délkeletről változatos összetételú, Erdélyi-középhegységből származtatható törmelékanyag áramlott be.

Az idősebb, a legtöbb esetben már cementált, tömör kőzetek (pl. mészkő, márga, homokkő, agyagkő, kovakőzetek) dezaggregálása (törés, oldás) után kinyert nehézásványok vizsgálata a bonyolultabb mintaelőkészítési eljárás miatt később kezdődött el, de annál szélesebb körú lehetôségeket kínált. Leginkább a forráskőzet és a lehordási terület meghatározása céljából vizsgálták többek között az észak-magyarországi permi-mezozoos (ZAJZON et al. 2011, VELLEDITS et al. 2017) és oligo-miocén törmelékes rétegsorok egyes tagjait (PAPP \& SEMPTEY 1956, KISS 1958). SzTANó \& JózsA (1996) a Pétervásárai Homokkő vékonycsiszolataiban változatos savanyú-neutrális magmás, meta- morf és üledékes kőzetfragmentumok mellett ofiolitos eredetû kőzetszemcséket (szerpentinit, metagabbró, metabazalt, radiolarit) mutattak ki, nehézásványai között ofiolitos eredetû́ metamorf ásványszemcséket (pl. aktinolit, pumpellyit, kékamfibol) is megfigyeltek. A mállékonyabb kőzettörmelékek fokozatos kimaradását rögzítették a Darnó-zóna menti forrásterületektől távolodva egészen Salgótarjánig, sôt kimutatták, hogy a nehézásványok és kőzetfragmentumok mennyiségének területi megoszlása összhangban van a szedimentológiai megfigyelések alapján megállapított tengeráramlási irányokkal és az ülepedés közbeni Darnó-zóna menti balos oldaleltolódással.

Az Északkelet-Dunántúl jura-alsó-kréta kőzeteiben Crspinellt mutattak ki (FÖLDVÁRI et al. 1973, VASKÓNÉ DÁVID 1988, CSÁSZÁr \& ÁrgYelán 1994, ÁrgYelán 1995, Árgyelán \& CsÁszÁr 1998, Árgyelán \& Horváth 2002), ami ofiolitos kőzetek lepusztulását jelzi. Ugyanezen a területen az eocén-oligocén rétegeket is többen vizsgálták. A korai munkák legnagyobb értéke a mikroásványok nagyon pontos és részletes leírása (VENDL 1932, SzTRÓKAY 1932), de következtetéseket is levontak a nagyszámban kimutatott kristályos kőzetekből származó nehézásvány lehetséges vepori (KASZANITZKY 1956), illetve közelebbi, nyugatra elhelyezkedő, mára már eltemetett alaphegységi forrásra vonatkozóan (VENDL 1932). A késóbbi kutatók vulkáni kőzeteket is megneveztek a lehetséges források között (CsÁNK \& SiPOSS 1962, CsÁNK 1963, SÁRKÖZINÉ FARKAS 1966). A Mecsek-Villányi térség mezozoos (FÜLÖP 1966, CsÁsZÁr et al. 2007, VARGA et al. 2009, PozSGAi et al. 2017), valamint miocén (RAVASZNÉ BARANYAi 1973, MiKLÓs 2018) rétegsoraiban zömmel a környék aljzatát felépítő közepes fokú metamorfitok és permi savanyú vulkanitok nehézásványait lehetett kimutatni.

A hazai bauxitok és szárazföldi vörös agyagok nehézásványvizsgálata egyrészt szintén a lehetséges forráskőzeteik és forrásterületük megismerését célozták meg, másrészt a bauxitok korbesorolását segítették elő (pl. Nézsa: KIss 1952; Iszkaszentgyörgy: VöRös 1958 és ANTAL 1973; Nagyegyháza: GECSE 1982; Dunántúli-középhegység, eocén fedő: DuNKL 1990; Dunántúli-középhegységÉszaki-Mészkőalpok: MindSZENTY et al. 1991; Vöröstó: KELEMEN et al. 2017).

Az optikai módszerrel történő mikroásvány-vizsgálatok a modern földtani kutatásban önmagukban már egyre kevésbé állják meg a helyüket, ugyanis az újabb és újabb nagymúszeres ásványelemzési módszerek megjelenése (mikro-röntgen diffraktometria, SEM-EDS/WDS, Ramanspektroszkópia, ionmikroszonda stb.) egyre pontosabb forráskőzet-meghatározást és azonosítást tesznek lehetővé. Mindezek mellett a mikromineralógia, ahogy a kőzetmikroszkópia is, sok esetben egy-egy szúkebb témakör (ásvány, zárvány stb.) további részletes vizsgálatához biztosítja a kiinduló mintákat és adatokat, valamint a szükséges mikroásványtani vagy kőzettani alapismereteket. Így — a teljesség igénye nélkül — végezhetünk ásványtani, nyomelem- és izotóp-geokémiai elemzéseket például homokból (homokkőből) vagy kavicsból (konglomerátumból) szepa- 
rált egyedi cirkon- vagy apatitkristályokon különböző kormeghatározásokhoz (pl. U-Pb kor: VARGA et al. 2012a, POZSGAI et al. 2017; hasadványnyom-kor: TARI et al. 1999), glaukonitszemcséken agyagásványtani és genetikai vizsgálatokhoz (FEKETE 2003), vagy talajból szeparált nehézásvány szemcséken (pl. epidot) mint indikátorásványokon érckutatás céljából (pl. folyamatban lévő diplomamunkák B. KIss G. témavezetésével, ELTE Ásványtani Tanszék).

Végezetül hadd említsük meg a lelkes amatôrök által, alkalmanként igen magas szakmai színvonalon végzett áldozatos kutatómunkát is, amellyel például folyóhordalékokban található mikroásványok szisztematikus leírását és vizsgálatát végzik, és amelyhez a szépség szeretete és a felfedezés öröme (pl. KöRMENDY 2015) adja a hajtóerőt.

\section{Törmelékes rétegsorok komplex eredetvizsgálata} (KEVi)

A forrásterület-kutatás hatékonysága szempontjából az előzőekben bemutatott mindhárom módszernek előnyeik mellett - komoly hiányosságai is vannak. A durvatörmelékek ugyan pontos képet adnak az állékonyabb forráskőzetekről, de nem mindig állnak megfelelő mennyiségben és minőségben rendelkezésre, terepi makroszkópos kôzethatározásuk nagyon időigényes és nem elég pontos, egyedi vékonycsiszolatos, statisztikus mennyiségú vizsgálatuk pedig hatalmas munkával és költséggel jár. A homokkövek vékonycsiszolatos vizsgálatának mintaelôkészítése ugyan viszonylag egyszerú, de kimérésük szintén munkaigényes, továbbá kisebb szemcseméretük miatt a homokszemcséket (elsôsorban a durvább szemcseméretú kőzetek töredékeit) nehéz pontos kőzettípusokba sorolni. A mikroásvány-vizsgálatok mintaelőkészítése bonyolult és költséges folyamat. A törmelékes kőzetekből kinyert nehézásványok lehetséges konkrét forráskőzethez rendelése pedig nem, vagy csak nagyon költséges módszerekkel, áttételesen lehetséges.

A laza törmelékes rétegsorok forráskutatásához ezért az ELTE Kőzettan-Geokémiai Tanszékének törmelékes üledékekkel és kőzetekkel foglalkozó kutatói a kavics és homok közötti átmeneti mérettartományba tartozó szemcséket is felhasználták. Ezzel a forrásterület-kutatásban máshol még nem alkalmazott módszerrel minden egyes mintavételi helyről egyetlen vékonycsiszolatban (,szemcsecsiszolat”) 300-400 darab kb. 2,0-2,5 mm-es (dara mérettartomány) szemcse mikroszkópos vizsgálata válik lehetővé (darakavics petrográfia; MiKLós \& JózSA 2017, MikLós et al. 2018). A módszer elsố alkalmazói (BRADÁK et al. 2013; SZEBERÉNYI et al. 2014, 2015) sikeresen különböztették meg egymástól a Börzsöny környéki vízfolyások (pl. Duna, Garam, Ipoly) és miocén képződmények törmelékanyagát.

Miklós \& JózsA (2017), valamint MikLós et al. (2018) a törmelékes összletek nehézásványainak biztos forráskőzethez rendelésére egy eddig még szintén nem alkalmazott módszert javasoltak. A törmelékes kőzetek mátrixából szeparált nehézásvány-együttest az adott összlet nagyobb méretú kavicsaiból szeparált nehézás- ványokkal vetették össze, így egyértelmúen megállapítható, melyik forráskőzethez melyik nehézásvány tartozik. A módszer elsô gyakorlati alkalmazása a nyugatimecseki alsó-miocén homokkő-konglomerátum (Szászvári Formáció) forrásterület-kutatásában kiváló eredményt hozott (MiKLós 2018).

A hagyományos vizsgálati módszerek és a kiegészítő két új vizsgálati módszer együttes alkalmazásával MıKLós \& JóZSA (2017) és MikLós et al. (2018) kidolgozták az ún. Komplex Eredetvizsgáló módszert (KEVi). Ez az új vizsgálatsorozat széleskörû kombinációs lehetőséget kínál arra, hogy az eddigieknél jobban megismerjük a laza törmelékes összletek lepusztulási területének kôzettani felépítését, annak időbeli kőzettani változásait és a szállításnak a lepusztult kôzetekre gyakorolt hatásait (MıKLós et al. 2018). Ezzel a korábban egyenként, vagy csak párban alkalmazott vizsgálatok eredményeinek bizonytalanságai csökkenthetők.

\section{Homokkövek diagenezise}

A diagenezis mindazon fizikai, kémiai és biológiai folyamatok összessége, amelyek az üledéklerakódást követően a földkéreg felsô részén játszódnak le (WORDEN \& BURLEY 2003, BogGS 2009). Ezek a különböző okokból végbemenő (pl. rétegterhelés, kémiai stabilitás változása) és intenzitású (pl. gyenge, mérsékelt, számottevő) átalakulások jelentôs mértékben befolyásolják az üledék összetételét és szövetét (pl. törmelékes vagy autigén ásványok, szemcsék érintkezési módja, porozitás). A leggyakoribb változások (pl. mechanikai vagy kémiai kompakció, cementáció) kisebb-nagyobb nyomokat hagynak maguk után, ezért a törmelékes kőzet petrográfiai vizsgálatával felvázolható az az út, amit az üledékanyag megtett a diagenezis során.

A Kárpát-Pannon térség törmelékes kőzeteinek petrográfiai vizsgálatával foglalkozó munkák többsége az oskörnyezeti viszonyok feltárásában és a lehordási terület kôzettani összetételének jellemzésében (pl. Gazzi-Dickinson-módszer alkalmazása; lásd a Homokkövek petrográfiai elemzése c. alfejezetet), azaz az eredetvizsgálatban hozott új eredményeket (pl. ÁrgYelán 1989; SZTANó \& JózSA 1996; VARGA et al. 2001, 2007; BODOR \& SZAKMÁNY 2009; FARICS et al. 2015; MikLÓs et al. 2018). Annak ellenére, hogy a magyar kutatók részletes összetételi és szöveti leírásra törekedtek, néhány kivételtől (pl. MÁTYÁs 1994, MÁTYÁs \& MATTER 1997, JuHÁSZ 1999, JuHÁsZ et al. 2002) eltekintve a diagenetikus eseménysor felvázolása általában nem volt céljuk.

A kémiai információval kiegészített petrográfiai módszerek (pl. festési eljárások alkalmazása; polarizációs, UV-fluoreszcens és katódlumineszcens mikroszkópia; elektronsugaras mikroanalízis) fejlődésével és hazai elterjedésével párhuzamosan az elmúlt kb. 10-15 évben egyre több olyan tanulmány született, mely a törmelékes kőzetekben megfigyelt jelenségeket a diagenetikus események 
szempontjából is értékelte. Több munka kísérletet tett a paragenetikai sorrend (a diagenetikus jelenségek egymást követő, időben értelmezett sorozata) felállítására is (pl. Sző́cs et al. 2015, VARGA et al. 2017, SzŐCS \& HiPs 2018, GYŐRI et al. 2020), ami egyértelmúen jelzi a homokkődiagenezissel foglalkozó kutatások jelentőségének a felismerését.

Figyelembe véve, hogy a homokkövek diagenezisének egyik kulcskérdése a porozitás változása a betemetődés során, továbbá a porózus homokkövek kiváló tárolókőzetek, a folyamatok feltárása sok esetben célzott ipari kutatásokhoz kapcsolódott. Ennek következtében számos adat bizalmas jellegú, ezért a diagenezissel kapcsolatos eredmények és értelmezések sok esetben nem, vagy csak korlátozottan kerültek nyilvánosságra.

\section{Porozitás, kompakció, cementáció: a diagenezis mozaikjai}

A Kárpát-Pannon térség paleozoikumi törmelékes üledékes kôzeteinek többsége a többfázisú diagenetikus folyamatok (pl. kompakció, cementáció, töréses deformáció) következtében már nem, vagy csak korlátozottan őrzi a korai diagenetikus események bélyegeit. Gyakori, hogy a betemetôdés miatt a kőzetet ért hatások már a metamorfózis alsó határát is átlépték (pl. a szilur Szalatnaki Agyagpala Formáció), ezért a diagenetikus fázisokra utaló petrográfiai ujjlenyomatok többsége felülíródott. A nem metamorf rétegsorok közül leggyakrabban a permokarbon homokkövek jellemzésekor találkozhatunk olyan megállapításokkal, amelyek a diagenezistörténet szempontjából is relevánsak (5. ábra $a$ és $b$ ). Ezek általában a cementásványok jellegérôl szolgáltatnak információkat (pl. VARGA et al. 2007, 2014), vagy a homokkővel összefogazódó finomszemcsés kifejlődésekben megjelenő zsugorodási szerkezeteket (pl. szeptáriás repedések), gumókat-konkréciókat, ritkábban a helyettesítéssel kapcsolatba hozható petrográfiai jellemzóket ismertetik (pl. KonRÁD et al. 2010, Máthé \& VARGa 2012, VARGA et al. 2012b, VARGA \& RAUCSIK 2014).

A mezozoikumi törmelékes kőzetek közül porózus vagy repedezett tárolóként több triász homokkô rétegsor diagenezistörténetét vizsgálták (5. ábra $c$ és $d$ ), néhány esetben a paragenetikai sorrend felállítását is megkísérelték (pl. Jakabhegyi Homokkő a dél-alföldi aljzatban; VARGA et al. 2015a, 2015b). Az Aggtelek-Rudabányai-hegység tengeri alsó-triász rétegsorába tartozó Bódvaszilasi Homokkő Formáció diagenezis-történetével kapcsolatban BoDoR et al. (2013) publikált petrográfiai megfigyeléseket. A Dunántúliközéphegység kevert karbonátos-sziliciklasztos rámpán kialakult alsó-triász rétegsorában megjelenô dolomitos aleurolit és homokkő (Hidegkúti Formáció, Zánkai Homokkő Tagozat) diagenezistörténetéről GYŐRI et al. (2020) közöltek komplex és korszerú vizsgálati eredményeket.

A magyarországi Paleogén-medence kis elterjedési területú, azonban a szénhidrogén-kutatás szempontjából kiemelten tanulmányozott képződménye a mezozoikumi aljzatra diszkordánsan települő Kosdi Formáció (alsó-priabonai), amelynek kezdő szakasza törmelékes üledékes kőzeteket (homokkő és konglomerátum) tartalmaz (RADOVICS et al. 2017; KöRMÖs et al. 2019a, 2019b). A képződményben kialakult tároló tagolt, amit elsôsorban a szakaszosan megjelenő, karbonáttal intenzíven cementált zónák okoznak (RADOVICS et al. 2017).

A Paleogén-medence egyik legfiatalabb képződménye az eggenburgi korú Pétervásárai Homokkő Formáció. Felszíni (Kishartyán) és mélyfúrási (Sámsonháza) szelvények kőzetmintáin végzett vizsgálatok integrált adatbázisának felhasználásával Szőcs et al. (2015) és Szőcs \& HIPS (2018) megállapították, hogy a sekélytengeri üledék betemetődése során — részben a mechanikai és a kémiai kompakció, részben a cementáció következtében - az elsődleges porozitás fokozatosan csökkent. A mezogenezis során az instabilis ásványok (pl. földpátok) oldódása, továbbá a kiemelkedés következtében a csapadék eredetú fluidumok oldó hatása miatt a porozitást növelő másodlagos pórusok alakultak ki. A porozitásfejlődés ismeretében a területre jellemző szerkezeti fázisokhoz igazodva a süllyedéstörténetet szintén felvázolták, amelyhez a homokkőben megjelenő deformációs szalagok feltételezett kialakulási idejét (késôi mezogenezis) vették alapul (BEKE \& FoDOR 2014, SzŐcs et al. 2015, BeKE et al. 2019). A Pétervásárai Homokkő elterjedési területének délkeleti részérôl, felszíni feltárásokból (Pétervásárai-dombság, Leleszi-völgy) származó, karbonáttal cementált konkréciók célzott petrográfiai vizsgálatával VERES \& VARGA (in press) a belsô karbonátforrás (bioklaszt eredetû aragonit/kalcit) szerepét mutatta ki a képződmény cementációja során (5. ábra e és f).

A neogén Pannon-medence pannóniai rétegsora tekinthetô hazánkban a diagenezistörténet szempontjából legtöbbet vizsgált, így legjobban ismert terrigén összletnek, bár az egyes részmedencékrôl rendelkezésre álló ismeretek mind a kutatás komplexitásában, mind a publikációk számában heterogének. A Pannon-medence neogén homokköveinek úttörő jellegú — ma is meghatározó jelentőségú —, a diagenezisre is kitérő komplex vizsgálatát MÁTYÁs (1994) végezte el. A Békési-medence és a kapcsolódó Battonyai-hát területérôl a Békési Konglomerátum és a Szolnoki Homokkő Formáció diagenezistörténetét ásványtani, kőzettani és geokémiai vizsgálatok eredményeire építve JUHÁsz (1999) részletezte. Megállapították, hogy a kiemelt kristályos hátak lényeges szerepet játszottak a medence hidrológiai és diagenetikus folyamataiban (JUHÁsZ 1999, JuHÁsZ et al. 2002).

Egy másik mélymedencében, a Makói-árokban az Endrődi Márga Formáció (Tótkomlósi Mészmárga Tagozat, mészmárga és homokkő) diagenezistörténetét komplex petrográfiai megközelítéssel TóTH et al. (2013; Makó-7 fúrás) vázolta fel, majd VARGA et al. (2017; Hódmezővásárhely-I fúrás) részletezte. Eredményeik alapján a polimikt, éretlen üledékanyag elsősorban lokális forrásból, a környező aljzatmagaslatok kőzeteinek eróziójából származott (6. ábra a és $b$ ). A karbonát legfontosabb forrásaként a törmelékes karbonátszemcséket jelölték meg, azaz a 


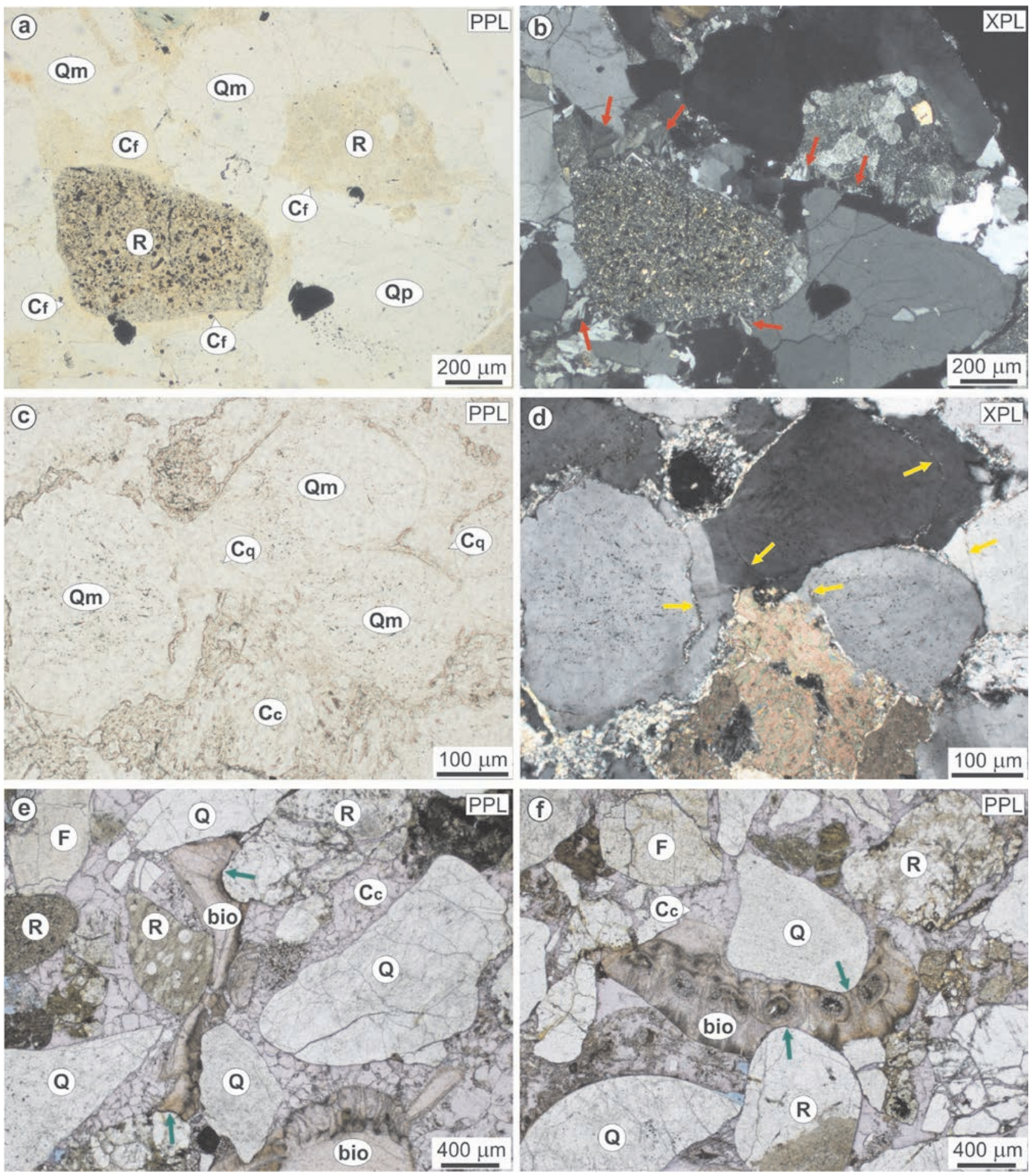

5. ábra. Jellegzetes cementtípusok

a) és b) Földpátcement (piros nyilak) permi homokkőben (Korpádi Homokkő Formáció, Siklósbodony-1 fúrás, 479,0 m); c) és d) Alsó-triász eolikus homokkő (Jakabhegyi Homokkó Formáció, Móra-1 fúrás, 17. magfúrási szakasz, 2310 m, Mórahalom). A kvarc szintaxiális továbbnövekedési cementet kalcitcement és helyettesítés követi. Az eredeti, jól koptatott szemcsehatárokat sárga nyilak jelzik; e) és f) Bioklaszt töredékekben gazdag, kalcittal cementált homokkő (Pétervásárai Homokkő Formáció, Leleszi-völgy, Kis-kő). A kémiai kompakciós bélyegeket (nyomási oldódás) zöld nyilak jelzik.

Röviditések: $\mathrm{Q}=$ kvarc; $\mathrm{Qm}=$ monokristályos kvarc; $\mathrm{Qp}=$ polikristályos kvarc; $\mathrm{F}=$ földpát; $\mathrm{R}=$ kőzettörmelék; bio = bioklaszt váztöredék; $\mathrm{Cc}=$ kalcitcement; $\mathrm{Cf}=$ földpátcement; $\mathrm{Cq}=$ kvarccement; PPL = egy nikolos fotó; XPL = keresztezett nikolok

Figure 5. Characteristic cement types

a) and b) Feldspar cemented (red arrows) Permian sandstone (Korpád Sandstone Formation, borehole Siklósbodony-1, 479.0 m); c) and d) Lower Triassic eolian sandstone (Jakabhegy Sandstone Formation, well Móra-1, core 17, 2310 m, Mórahalom). Note: syntaxial quartz overgrowth is postdated by calcite cement and replacement. Well-rounded grain boundaries are marked by yellow arrows; $e$ ) and f) Bioclast fragment-rich and calcite cemented sandstone (Pétervására Sandstone Formation, Lelesz Valley, Kiskö Hill). Features of chemical compaction (pressure dissolution) are indicated by green arrows.

Abbreviations: $Q=$ quartz; $Q m=$ monocrystalline quartz; $Q p=$ polycrystalline quartz; $F=$ feldspar; $R=$ rock fragment; bio $=$ bioclast fragment; $C c=$ calcite cement; $C f=$ feldsparcement; $C q=q u a r t z$ cement; $P$ PL = Plane Polarized Light; $X P L=$ crossed nicols 

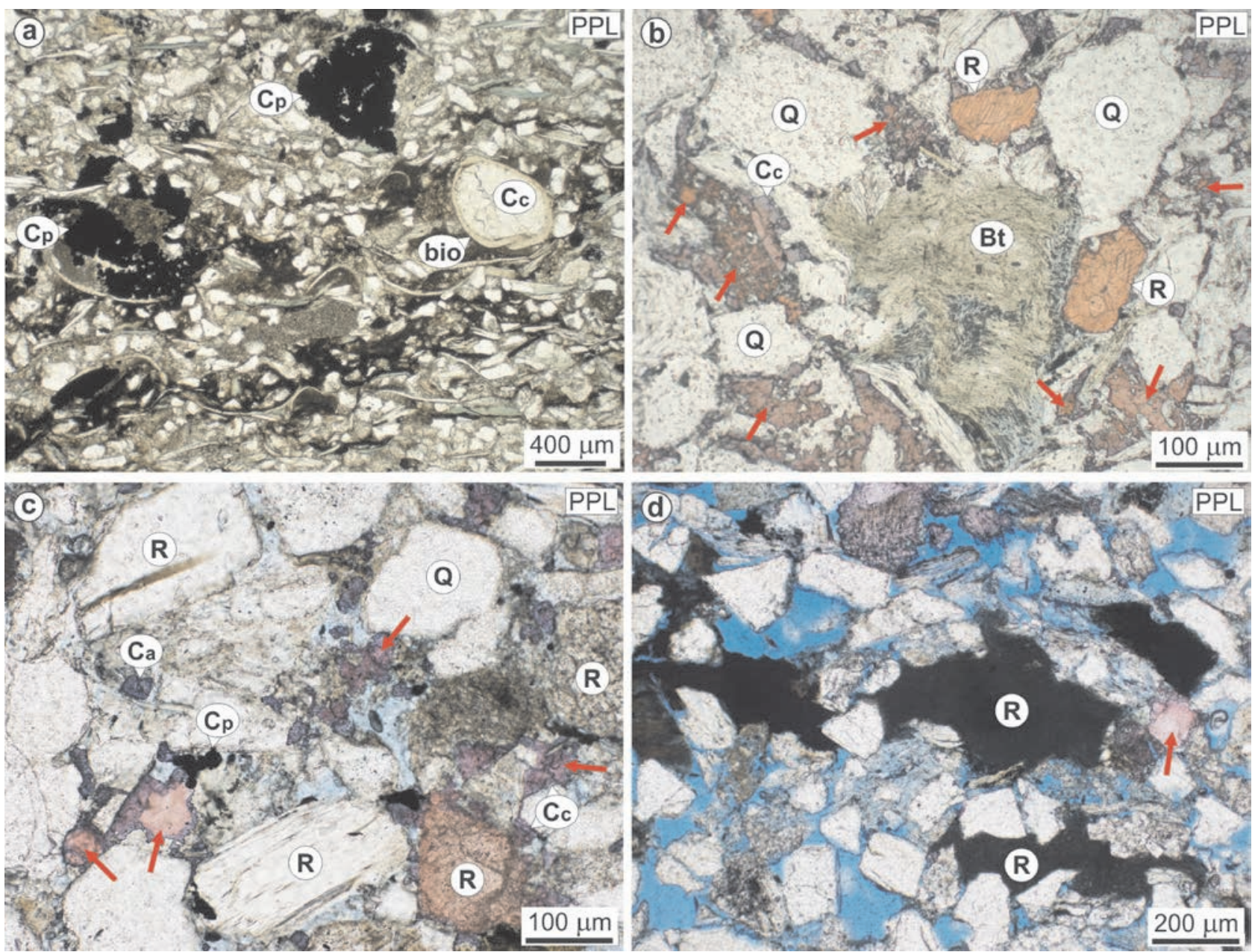

6. ábra. Neogén (pannóniai) homokkövek diagenezise

a) Bioklaszt (ostracoda) héjakban gazdag, pirittel és kalcittal cementált homokkő (Endrődi Márga Formáció, Hódmezővásárhely-I fúrás, 40. magfúrási szakasz, 5481 m). A korai diagenetikus piritcement framboidális halmazok formájában figyelhetỏ meg; b) Karbonátos kőzettörmelékben (halványpiros szemcsék) gazdag, vastartalmú kalcittal (lila) cementált homokkő (Endrődi Márga Formáció felső része, Hódmezővásárhely-I fúrás, 28. magfúrási szakasz, 4540 m; festett vékonycsiszolat). Az erősen átalakult, expandálódó biotit belsejében másodlagos mikropórusok alakultak ki; c) és d) Foltokban cementált homokkő (Újfalui/Algyői Formáció, H-1 fúrás, 1625 m, Szeged, festett vékonycsiszolatok). Cementként vastartalmú kalcit, ankerit és pirit (c) figyelhetỏ meg. A feltépett agyagklasztok (d) képlékenyen deformálódtak. Megjegyzés: a pórusokat kékre festett mủgyanta tölti ki. Jelmagyarázat: $\mathrm{Bt}=$ biotit; $\mathrm{Q}=$ kvarc; $\mathrm{R}=$ közettörmelék; bio = bioklaszt váztöredék; $\mathrm{Ca}=$ ankeritcement; $\mathrm{Cc}=$ kalcitcement; $\mathrm{Cp}=$ piritcement; $\mathrm{PPL}=$ egy nikolos fotó; piros nyilak = törmelékes karbonátszemcse (pátos kalcit vagy mészkőklaszt) reliktuma

Figure 6. Neogene (Pannonian) sandstone diagenesis

a) Bioclast-rich (Ostracods), pyrite and calcite cemented sandstone (Endröd Marl Formation, well Hódmezóvásárhely-I, core 40, 5481 m). Early diagenetic pyrite cement is developed as framboidal aggregates; b) Carbonate rock fragment-rich (pale red grains) ferroan calcite cemented (lilac) sandstone (upper part of the Endröd Marl Formation, well Hódmezövásárhely-I, core 28, $4540 \mathrm{~m}$, stained thin section). Note: secondary micropores are present within the strongly altered and expanded biotite grains; $c$ ) and d) Patchy cemented sandstone (Uifalu/Algyo Formations, well H-1, 1625 m, Szeged, stained thin sections). Ferroan calcite, ankerite, and pyrite aggregates (c) are present as cement material. Reworked mudrock clasts (d) show ductile deformation features. Note: pores are filled by blue dyed epoxy;

Legends: $B t=$ biotite; $Q=$ quartz; $R=$ rock fragment; bio $=$ bioclast fragment; $C a=$ ankerite cement; $C c=$ calcite cement; $C p=$ pyrite cement; $P P L=P l a n e$ Polarized Light; red arrows $=$ relic of detrital carbonate fragment (sparitic calcite or limestone)

diagenezis során belsô eredetú forrással magyarázták a cementációt. Hasonló következtetést fogalmazott meg SiNKó (2014) a Hódmezôvásárhely-I fúrásban feltárt Szolnoki Homokkő Formáció képződményeinek petrográfiai vizsgálata során. Megállapította, hogy az éretlen, instabilis szemcsék közeli forrásra (pl. szomszédos aljzati hátak) utalnak. A metamorf és üledékes kőzettörmelék szemcsék (uralkodóan dolomit, kisebb arányban mészkő) aránya, valamint az akcesszórikus gránáttöredékek mennyisége a mélység csökkenésével növekszik. A meghajló, hullámos csillámok, továbbá a szemcsék között elvékonyodó szerves anyagos filmek (szenesedett növénymaradványok) a kompakció hatását jelzik a diagenezis során. Cementként az eltérő vastartalmú pátos kalcit a leggyakoribb, bár a kalcit deformációs ikres ásvány- vagy kőzettöredék formájában szintén megtalálható. A petrográfiai képanalízis segítségével meghatározott legnagyobb makroporozitást (3-8\%) a fúrás 4260-4270 m közötti tartományában figyelte meg a szerző, ami a Szolnoki Homokkő legalsó szakaszát jelenti a vizsgált fúrásban. Genetikáját tekintve másodlagos szemcseoldódási pórusokat azonosított, amelyek gyakran a csillámok átalakulásához (pl. expandálódó biotit) kapcsolódtak. A fiatalabb települési helyzetben lévő képződményekben a pórusokat szinte teljesen kitöltötte a karbonátcement $(<3-5 \%$ makroporozitás). 
Az aljzatmagaslat feletti helyzetben található szegedi geotermikus rezervoár jellemzése céljából a 2017-ben mélyült H-1 (Szeged) fúrás Algyői, illetve Újfalui Formációba sorolt szakaszait (1620-1800 m) VARGA et al. (2019) vizsgálták. A lokális forrásból származó, ásványos összetételüket tekintve éretlen, kevert sziliciklasztos és karbonátos (a dolomit- és mészkőtörmelék mennyisége elérheti a 20-25\%-ot) szemcséket tartalmazó homokkő-rezervoárban számottevő makroporozitást figyeltek meg (6. ábra c és $d$ ). A porózus kőzetekben a makroporozitás becsült értéke $5-25 \%$ közötti, de lokálisan tökéletesen cementált szakaszokat is dokumentáltak. A pórusok többnyire részlegesen redukált elsődleges szemcseközi pórusok, de a szelektíven kioldódó földpátok belsejében szemcsén belüli másodlagos oldódási pórusokat szintén leírtak. Ásványtani vizsgálataik alapján a meteorikus fluidumok hatására a földpátok átalakulási termékeként kis mennyiségben kaolinit jelent meg, mint agyagásvány cement. Megállapították, hogy a kapcsolódó pelites üledékben jelentôs az éretlen szerves anyag mennyisége, ami befolyásolta a korai diagenezis eseményeit. A vizsgált mintákban a bakteriális szulfátredukcióra visszavezethető framboidális pirit, továbbá a vastartalmú kalcit a fő cementfázisok; a kalcitcement forrását belsô eredetưnek ítélték meg.

A tárolókőzetek kutatása szempontjából a Szolnoki Homokkő kiemelt figyelmet kapott, hiszen nemcsak a szénhidrogének feltárása, hanem a szén-dioxid felszín alatti tárolása kapcsán is előtérbe került. SENDULA (2015) és KIRÁLY et al. (2019) a kb. 1500-2250 m mélységből származó homokkövek (Zagyvarékas) törmelékes ásványainak azonosítása mellett a diagenetikus ásványokat is meghatározták. A Kisalföldön található Mihályi-Répcelak természetes $\mathrm{CO}_{2}$ előfordulás pedig kiváló lehetőséget biztosított arra, hogy a pannóniai porózus tárolóban a külsố forrásból származó $\mathrm{CO}_{2}-$ felhalmozódás diagenetikus hatását is tanulmányozzák (KIRÁLY 2017). Megállapította a szerzô, hogy a $\mathrm{CO}_{2}$ beáramlását követően megváltozott pH hatására először karbonát-, majd szilikátoldódás zajlott. A felszabaduló komponensekből dawsonit és második generációs kaolinit képződött, a $\mathrm{SiO}_{2}-$ tartalom (kovasav) pedig a kvarc továbbnövekedési cement kialakulásához járult hozzá. A fenti folyamatokat késői karbonátcement kialakulása követte (KIRÁLY 2017).

$\mathrm{Az}$ országhatárt átlépve az Erdélyi-medence neogén rétegsorában a mélytavi turbiditrendszerek a Kárpát-Pannon térség ismert szénhidrogén-rezervoárjai közé tartoznak. A feltöltôdés egy késôi fázisát képviselik azok a pannóniai feltárások (Firtosmartonos/Firtănuş, Kismedesér/ Medioru Mic, Románia), amelyek szedimentológiai és diagenezistörténeti jellemzőit BARTHA et al. (2016) vizsgálták. A közeli lehordási területről (Kárpátok) származó törmelékből éretlen, közepes-gyenge osztályozottságú, finom-nagyszemcsés, kőzettörmelékes homok rakódott le. A diagenezis során a plasztikusan deformálódó szemcsék (pl. mállott kőzettörmelék) fizikai kompakciója lényeges szerepet kapott a porozitás csökkentésében. Ehhez változó mértékú cementáció társult, viszonylag porózus (porozitás: 15-20\%) vagy teljesen cementált (porozitás: max. 1\%) homokkövet eredményezve. Következtetésük szerint az így kialakult heterogén porozitáseloszlás alapvetően befolyásolja a fluidumok áramlását, illetve a tárolókőzet tulajdonságait (BARTHA et al. 2016).

\section{Archeometriai vonatkozások}

A homokkő az emberiség történetében már nagyon régóta használatos nyersanyag, belőle elsősorban őrlőkő, malomkő, csiszolókő, fenőkő készült (7. ábra; T. BIRó 1992). Csiszolt kőeszközt azonban csak elvétve készítettek homokkôből, mivel annak szemcséi legtöbbször csak gyengén tapadnak és mechanikai hatásra könnyen kiperegnek. A későbbiek során — egészen a 20. század végéig — több homokkő változatot (pl. permotriász vörös homokkő, Hárshegyi Homokkő) faragott kôként, illetve építőkőként (8. ábra) is felhasználtak (pl. TöRÖK 2008), ezekről

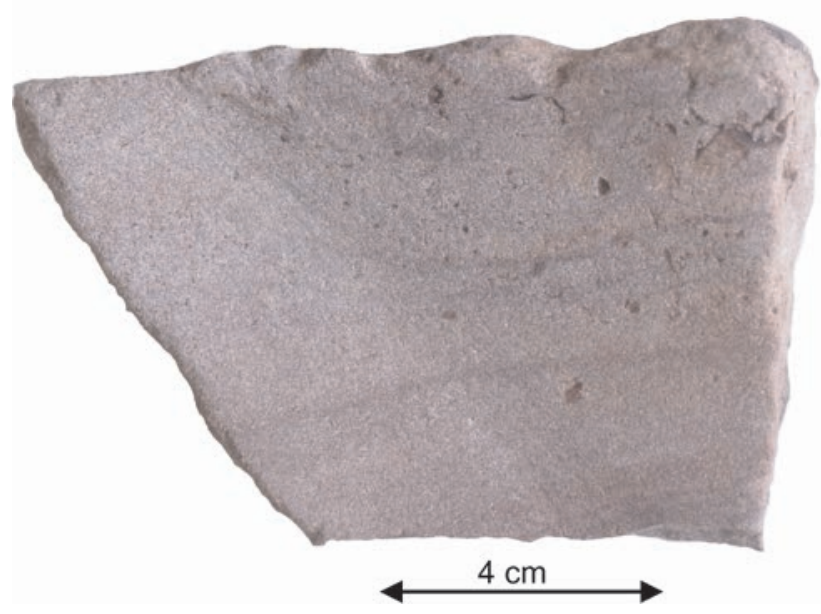

7. ábra. Kőeszközök csiszolásához használt lila, keresztrétegzett homokkőbő készült fenőkő töredéke (Gorzsa, GOR-80 minta)

Figure 7. Whetstone fragment made of layered lilac sandstone used for burnishing polished stone tools (Gorzsa, sample GOR-80)
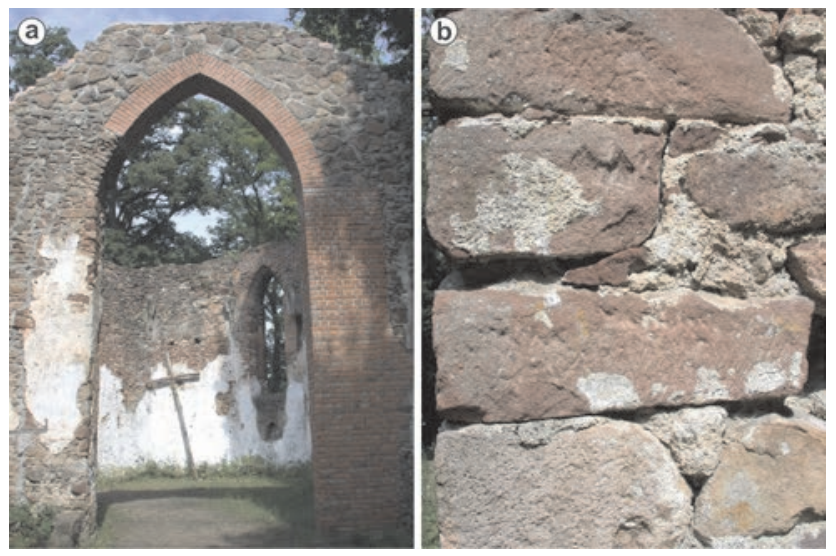

8. ábra. Helyi nyersanyagból (Balatonfelvidéki Homokkő Formáció) épült a középkorban az Ábrahám-hegyen a salföldi pálos kolostor, amelynek impozáns romjai még ma is láthatók. a) Késő gótikus kapu; b) A fal szorosan egymáshoz illeszkedő faragott homokkő tömbökből áll

Figure 8. Ruins of Medieval Salföld Pauline Monastery (Ábrahám Hill, Balaton Highland) built from local red sandstone raw material (Balatonfelvidék Sandstone Formation). a) Late Gothic gate; b) The wall is composed of tightly fitted carved sandstone blocks 
azonban — terjedelmi okok miatt — ebben a részben nem ejtünk szót.

A homokkövek archeometriai feldolgozása, ami elsősorban mikroszkópos petrográfiai vizsgálatot jelent, még viszonylag kezdeti fázisban jár. Számos esetben kizárólag makroszkópos kőzethatározás, esetenként csak nagyon rövid leírás készült róluk, megjelölve a homokkő színét, ritkábban a szemcseméretét és osztályozottságát (pl. Antonović 2008, KACZANOWSKA et al. 2011). Ezáltal a nyersanyag származási helyét csak nagyon tágan és jelentős bizonytalansággal lehet megadni. Vékonycsiszolatos petrográfiai vizsgálatok eddig csak kevés lelőhelyről és korból előkerült leletanyagon történtek (pl. SZAKMÁNY 1996, SZAKMÁNY \& NAGY 2005, PÉTERdi 2012), jóllehet ezek a részletes leírások a szóba jöhetô nyersanyagok származási helyét már leszúkíthetik. Ugyanakkor a különböző területek homokköveinek részletes petrográfiai leírása, sôt azt kiegészítô ásványkémiai vizsgálata eddig háttérbe szorult. Kiegészítő mikromineralógiai vizsgálatok elsősorban csak laza homokból vagy recens - elsôsorban folyóvízi - üledékből készültek. A homokkövek jelentős része — néhány jellegzetes nehézásványon kívül — általában ritkán tartalmaz olyan diagnosztikus elegyrészeket, amelyek a petrográfiai alapon történô proveniencia meghatározását megkönynyítenék. Ezért azokban a homokkövekben, amelyek nem tartalmaznak jellemző nehézásvány-együttest, kiegészítő vizsgálatok (pl. földpátok, csillámok összetételi meghatározása, CL-vizsgálatokkal a különbözố eredetú kvarcszemcsék azonosítása stb.) lenne szükséges. A közelmúltban elkezdett, úttörố jellegû́ komplex feldolgozások azt mutatják (MıKLós et al. 2019), hogy a homokkő anyagú szerszámkövek és a potenciális nyersanyaglelőhelyról származó törmelékes kôzetek összehasonlító vizsgálata kecsegtetô eredményeket hozhat a jövőben.

Homokkő anyagú szerszámkövek elsô részletes petrográfiai feldolgozása és a potenciális nyersanyaglelőhely meghatározása a Bicske-Galagonyás (középső-neolit, SopotBicske kultúra) lelőhelyen talált homokkő eszközök esetében történt (SZAKMÁNY 1996). A homokkövekben többek között - Cr-spinell volt felismerhető, amellyel együtt glaukonit, illetve többféle ofiolitos eredetú vagy annak képződési környezetében előforduló kőzettörmelék is előfordult (SZAKMÁNY 1996). A Gerecse-hegységben ÁRGYELÁN (1995) és CSÁSZÁR \& ÁRGYELÁN (1994) részletes petrográfiai vizsgálatot végeztek az alsó-kréta Lábatlani Homokkőről, amelynek törmelékanyaga teljességgel hasonló a kőeszközökben előforduló törmelék összetételével. Ezáltal a Lábatlani Homokkő neolitikumban történó felhasználása bizonyítást nyert (SZAKMÁNY 1996).

A vörös homokkô már ôsidők óta az egyik leginkább elterjedt típus a magyarországi (neolit, rézkori, bronzkori) homokkő anyagú szerszámkő leletanyagokban (pl. Gorzsa, késő-neolit: SZAKMÁNY et al. 2008, 2009, 2011; STARNINI et al. 2015; Balatonlelle-Felső-Gamász: SZAKMÁNY \& NAGY 2005; Balatonőszöd: PÉTERDI 2012; Vatyai kultúra, bronzkor: FARKAS 2013, FARKAS-PETŐ \& HoRVÁTH 2014, FARKASPETő et al. 2014). Elsősorban őrlőkőként és csiszolókőként, emellett a keményebb és szívósabb változatokat ütőkőként használták. Az archeometriai feldolgozás során a vörös homokkő a színe alapján már makroszkóposan is jól elkülöníthetô a többi homokkőfajtától, de a vörös homokkövek különböző nyersanyaglelőhelyeirôl származó típusainak elkülönítése csak a legutóbbi időkben kezdődött meg. Az elkülönítést egyrészt nehezíti, hogy a vörös homokkövek kárpát-medencei, illetve közvetlen környékbeli előfordulásairól a Balaton-felvidéki, illetve a mecseki előfordulásokon kívül nem, vagy csak elvétve (és csak átnézetes formában) állnak rendelkezésre petrográfiai mikroszkópi leírások. Kémiai elemzések pedig szintén csak elvétve, és elsősorban a mecseki terület fúrásaiból származó homokkövekből készültek.

A gorzsai késő-neolit, Tisza-kultúrába tartozó lelőhelyen a hosszabb ideje tartó folyamatos feldolgozás során a vörös homokköveknek egyre több típusát sikerült elkülöníteni elsősorban petrográfiai és részben geokémiai vizsgálatok alapján (SZAKMÁNY et al. 2008, 2009, 2011; PIROS 2010; StARnini et al. 2015; MiKLós et al. 2019). Az eredmények azt mutatják, hogy a Balaton-felvidéki permi, illetve a mecseki permotriász homokkövet egyaránt felhasználták, ugyanakkor más típusú vörös homokkő nyersanyagú leletanyagok is előfordultak. Ezek eredetének felderítésére megkezdődött a kárpát-medencei vörös homokkövek előfordulásainak részletes archeometriai szempontú feldolgozása és a régészeti leletanyagokkal való összevetése egy doktori munka keretében. Az elsô eredmények alapján a Balaton-felvidéki és a mecseki lelőhelyeken kívül a Papukhegység permotriász rétegsorának feltárásaiból, a mecseki miocén kavicsösszletből, valamint pleisztocén és recens folyók kavicsösszletéből (Duna, Maros) származó kavicsanyag vizsgálatai kezdődtek meg. A nagy energiájú közegből származó kavicsanyag ugyanis kiválóan alkalmas ütőkőnek, lévén az összlet képződése során már egy előzetes természetes szelekción átesik, és csak a mechanikailag ellenálló kavicsok/tömbök maradnak meg, amelyeket az őskori emberek akár közvetlenül is fel tudtak használni munkájuk során. Gorzsán valószínúsíthetően a Marosból származó vörös homokkő kavicsokat használták (9. ábra), ami a régészeti eredményekkel is jó összhangban van (MikLós et al. 2019).

A Gorzsán előkerült Tisza-kultúrabeli neolit leletanyagban a vörös homokkő változatokon kívül más típusú homokkő nyersanyagból készült kőeszközök is előfordulnak (SZAKMÁNY et al. 2008, 2009, 2011; STARNINI et al. 2015). Ezek közül kiemelendő a szürke homokkő egyik változata, amelyben az akcesszóriák között jelentős mennyiségú gránát, valamint kis mennyiségben Cr-spinell is előfordul. A szürke homokkő ezen változata jelentős hasonlatosságot mutat a Gosau-típusú kréta homokkő változataival, amelyek az Erdélyi-középhegységben jól ismertek (Schuller \& Frisch 2006, Schuller et al. 2009). A nyersanyag lelőhelyének pontosabb meghatározása azonban még a jövő feladata lesz.

A Balatonlelle-Felsô-Gamász késô rézkori lelőhelyen vizsgált őrlőkövek petrográfiai mikroszkópos vizsgálata 


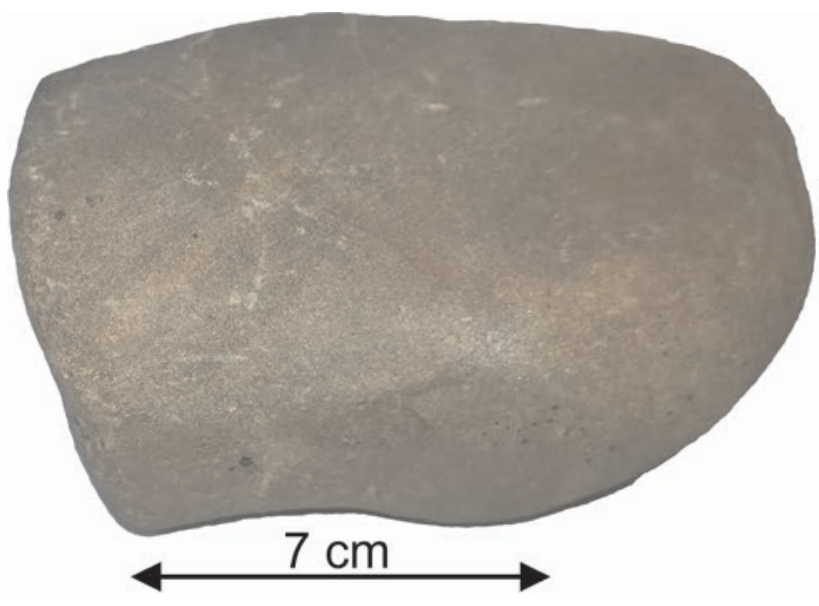

9. ábra. Ütőkőként használt tömött, masszív vörös homokkő anyagú kavics (Gorzsa, GOR-435 minta)

Figure 9. Hammerstone made of massive and hard red sandstone pebble (Gorzsa, sample GOR-435)

alapján a felhasznált nyersanyag kőzettörmelékes homokkő (litarenit) volt. A benne előforduló elegyrészek megjelenése és azok mennyiségi arányai, valamint a kötőanyag jellemzői alapján a homokkő nyersanyag a Balatonfelvidéki Homokkő Formációból származik, annak is a kvarc- és kőzettörmelék anyagú, érett homokkő típusával mutat hasonlatosságot, amelyek a déli terület peremi részein, illetve az északi területen a rétegsorok alsó részein jellemzőek (SZAKMÁNY \& NAGY 2005).

A balatonőszödi badeni (rézkori) lelőhelyen nagy mennyiségú vörös homokkőből készült szerszámkő fordult elő. Ezek reprezentatív példányainak vékonycsiszolatos vizsgálata alapján túlnyomó részük a Balatonfelvidéki Homokkő Formáció balatonlellei előfordulásáéhoz hasonló homokkövekből készült. Emellett néhány, összetételét tekintve eltérő kőeszköz nyersanyagául nagy valószínúséggel a mecseki permotriász rétegsor Jakabhegyi Homokkő Formációjának felsô részén előforduló kôzeteket használták (PÉTERDI 2012).

A bronzkorban szintén elterjedt volt a változatos homokkő nyersanyagú szerszámkövek készítése és használata, emellett kis számban csiszolt kőeszközök is készültek homokkőből (pl. FARKAS 2013, FARKAS-PETŐ et al. 2014). A vékonycsiszolatos petrográfiai vizsgálatok alapján a vörös homokköveket részben a Balaton-felvidék területéról, kisebb valószínúséggel a Mecsekból (Jakabhegyi Homokkő, illetve a Kővágószőlősi Homokkő) származtatják (FARKAS 2013, FARKAS-PETŐ \& HORVÁTH 2014, FARKASPETŐ et al. 2014). A nem vörös homokkövek esetében egyrészt Hárshegyi Homokkövet, másrészt többféle neogén homokkövet is használtak. Ez utóbbiak közül a Budafoki és a Törökbálinti Homokkő Formációba, illetve a Budafai Formációba tartozó homokköveket feltételezik nyersanyagként. A neogén homokköveket csiszolókőnek, továbbá jó faraghatóságuk és viszonylag jelentős porozitásuk miatt öntőformák készítésére is használták (FARKAS-PETŐ \& HorvátH 2014, FARKAS-PETó et al. 2014). Ugyancsak Hárshegyi Homokkő nyersanyagú csiszolt kőeszközről számolt be a Miháldy-gyưjteményből FÜRI \& SZAKMÁNY (2004), sőt a Szigetszentmiklóson feltárt bronzkori temetôből előkerült néhány szerszámkő eredeteként is ezt a képződményt jelölték meg (KALMÁR \& VICZE 2006).

A vaskori öntőformák egy része finomszemcsés, kalcitos kötőanyagú, erősen porózus (ami az öntés során felszabaduló gázok távozását elősegíti), emiatt többnyire jól faragható, puha homokkőből készült. A nyersanyag pontos származási helyének azonosítása egyelőre nem történt meg, összetétele alapján azonban valószínúsíthetően karbonátos kötőanyagú pannóniai homoklencsékből vagy rétegekből származhat (PÉTERDi 2004, PÉTERDI et al. 2005).

PALÁGYI et al. (2006) vörös homokkőből készült római kori faragványok nyersanyagának pontos származási helyét próbálták meghatározni. Ehhez a Balaton-felvidéken a római, 2-4. században múködő vörös homokkő bányákból gyưjtöttek és elemeztek összehasonlító mintákat. A származási helyet a faragványok és a bányaminták ICP-AES módszerrel mért kémiai összetétele alapján kísérelték meghatározni. Eredményeik alapján a nyersanyagokat a balatonalmádi Keleti-kőfejtô és az Alsóörs-Alsóhegy bányákból származtatták, illetve egy oltár tekintetében nem zárták ki, hogy a homokkő Balatonrendes környéki kőfejtőből származik. Mindezekből arra következtettek, hogy a rómaiak a különböző típusú faragványokhoz más-más bányákból származó nyersanyagot használtak.

A regölyi kora vaskori sírhalomból igen jelentős mennyiségú, több mint 4000 darab kőtömb került elő, amelyek 3,2\%-a volt homokkő anyagú. Döntően kétféle változat volt elkülönítethetô: kovás, illetve meszes kötőanyagú. Az előbbi összetétele alapján egyértelmúen azonosítható volt a permi Balatonfelvidéki Homokkővel (KÜRTHY et al. 2013). A meszes kötőanyagú változat törmelékszemcséi és cementanyaga alapján a zamárdi Szamárkő pannóniai homokkő összetételéhez hasonló (KüRTHY szóbeli közlés, 2020).

Összefoglalóan: habár a homokkövek archeometriai célú feldolgozottsága még csak kezdeti stádiumban van, már az eddigi eredmények is jelzik, hogy érdemes részleteiben foglalkozni ezzel a kutatási iránnyal. A részletes mikroszkópos petrográfiai vizsgálat jelentős segítséget nyújthat a kőeszközök származásának lehatárolásában, ezáltal a korabeli kapcsolatrendszerek feltérképezésében is.

\section{Következtetések}

Az elmúlt 150 év óriási mennyiségú és témáiban is változatos publikációi egyértelmúen jelzik, hogy a törmelékes üledékek és kőzetek nagyon fontos szerepet játszanak a földtörténeti múlt eseményeinek feltárásában, a nyersanyagkutatásban (pl. fluidumok felszín alatti tárolása: kőolaj, földgáz és nem utolsósorban a víz), sốt a jelenkori felszínformáló erôk, talajképző folyamatok vagy környezeti problémák jellemzéséhez is számos megközelítési lehetőséget biztosítanak. Ez a kôzetcsoport sok esetben olyan régen lepusztult, a felszínen vagy fúrásokban ma már meg 
sem található képződmények maradványait is tartalmazza, amelyek vizsgálati eredményei fontos láncszemek a régmúlt eseményeinek nyomozásában.

Annak ellenére, hogy a hazai szakirodalom bővelkedik a törmelékes üledékek és kőzetek széles módszertani palettát lefedő kutatási eredményeiben, ma sem jelenthetjük ki, hogy „már mindent tudunk”. A kiváló kutatók nyomdokain elindulva, a folyamatosan fejlődő, meg-megújuló vizsgálati módszerek tárházát kihasználva a korábbi megfigyelések pontosíthatók, vagy új kérdések tehetők fel. Ezek megválaszolása azonban csak részben a napjainkban aktív kutatók feladata. Figyelembe véve a 21. század megváltozott igényeit, a törmelékes kőzetek kutatása érdekes és hasznos szakmai kihívást jelent a jövő geológusai számára is. Reméljük, minél több lelkes fiatal szakember veszi át a stafétabotot!

\section{Köszönetnyilvánítás}

Először is köszönjük a bizalmat a Földtani Közlöny szerkesztőségének, hogy e létszámában ugyan mára már erősen megfogyatkozott, mégis kiváló szakembergárdából minket kértek fel e megtisztelő, nemes feladatra, az elmúlt 150 év törmelékes üledékek és üledékes kőzetek petrográfiai vizsgálataira vonatkozó hazai tudományos eredmények összefoglaló értékelésére. Hálásak vagyunk továbbá mindazoknak, akik a földtani szakfolyóiratok nagy részének korlátlan internetes elérhetőségét megteremtették. Legnagyobb tisztelettel szeretnénk adózni mindazon nagyszerú tudós, kutató és ipari szakember elődeink előtt, akik tudásuk és életük legjavát áldozták szeretett szakmájukra, a földtudományra, illetve a geológiára, és írásaikkal megteremtették a lehetôséget arra, hogy az általuk felhalmozott mérhetetlen gazdag szakmai tudást mint örökséget megkaphassuk, megismerhessük, és vissza-visszanyúlva belőle mindig táplálkozhassunk. Végül köszönetünket szeretnénk kifejezni mindazon geológus és földtudományi egyetemi hallgatóknak, akiknek kitartó és lelkes terepi és laboratóriumi munkája pótolhatatlan alapadatokkal szolgált az időigényes feladatokban (pl. kavicsstatisztika, modális kimérés).

Tanulmányunk gondos bírálatáért Mikes Tamásnak, SzILÁGYi Veronikának és ThAmóné Bozsó Editnek mondunk köszönetet. Megjegyzéseik, kiegészítéseik érdemben hozzájárultak a kitûzött célok megvalósításához.

Az SZTE-n folyó homokkő petrográfiai és diagenezistörténeti oktató- és kutatómunkát (VA) az NKFIH K 108375 és K 131690 témaszámú projektjei, az MTA Bolyai János Kutatási Ösztöndíja (BO/266/18) és az Innovációs és Technológiai Minisztérium ÚNKP-19-4-SZTE-34 kódszámú Új Nemzeti Kiválóság Programja támogatja.

\section{Irodalom - References}

ALMÁDy Z. 1988: A tatai Kálvária-domb és környékének karsztjelenségei. — Karszt és Barlang 1988/1, 3-14.

ANTAL, S. 1973: Micromineralogical and textural features in relation to the genesis of bauxite of Iszkaszentgyörgy. - Acta MineralogicaPetrographica, Szeged 21/1,3-16.

Antonović, D. 2008: The development of the ground stone industry in the Serbian part of the Iron Gates. — In: Bonsall, C., BoronEANT, V. \& RAdovanović, I. (eds.): The Iron Gates in Prehistory: New perspectives. BAR International Series 1893, Archaeopress, Oxford, 19-38.

ÁrgYelán, G. B. 1989: Detrital framework analysis of Lower Cretaceous turbidite sequence of Neszmély-4 borehole (W. Gerecse Mts., Hungary). - Acta Mineralogica-Petrographica, Szeged 30, 127-136.

ÁRGYELÁN G. B. 1995: A gerecsei kréta törmelékes képződmények petrográfiai és petrológiai vizsgálata. — Általános Földtani Szemle 27, 59-83.

ÁRgYelÁN G. B. \& CSÁsZÁR G. 1998: Törmelékes krómspinellek a gerecsei jura képződményekben. — Földtani Közlöny 128/2-3, 321-360.

Árgyelán, G. B. \& Horváth, P. 2002: Heavy mineral assemblages of Senonian formations in the Transdanubian Range, Hungary. Acta Geologica Hungarica 45/4, 319-339 https://doi.org/10.1556/AGeol.45.2002.4.1

BÁLdi T. \& NAGYMARosi A. 1976: A Hárshegyi Homokkő kovásodása és annak hidrotermális eredete. — Földtani Közlöny 106/3, $257-275$.

Báldi T., B. Beke M., Horváth M., Kecskeméti T., Monostori M. \& Nagymarosi A. 1976: A Hárshegyi Homokkő Formáció kora és képződési körülményei. — Földtani Közlöny 106/4, 353-386.

Balog K., Kalmár J., Kuti L., SzABó A., Fodor N. \& TóTH T. 2013: Homokos talajok összehasonlító ásványtani és szemcsemorfológiai vizsgálata tiszántúli erdôs és füves területeken. — Agrokémia és talajtan 62/2, 267-284., https://doi.org/10.1556/agrokem.62.2013.2.7

BARÁTOSI J. (szerk.) 1961: Beszámoló az M.K.B.T. egri ifjúsági csoportjának 1960. évi munkájáról. — A magyar karszt és barlangkutató bizottság tájékoztatója. Kiadja a Magyar Karszt- és Barlangkutató Bizottság, Budapest, 18 p.

BARABÁSNÉ STUHL Á. 1981: A Kővágószőlősi Homokkő Formációt alkotó kisciklusok földtani vizsgálata. — Földtani Közlöny 111/1, $26-42$.

Barbacka, M., Szakmány, Gy. \& Józsa, S. 1997: Upper Carboniferous Flora from newly collected pebbles of the Miocene Conglomerate in the western Mecsek Mts. (southern Hungary). — Acta Paleobotanica 37/1, 5-11.

BÁRDOSSY GY-NÉ 1958: A fehérvárcsurgói (Dunántúl) pannóniai kvarchomok üledékföldtani vizsgálata. — Földtani Közlöny 88/2, 228-236.

BARTHA I. R., SzőCs E. \& TőKÉs L. 2016: Rezervoár analóg pannóniai turbiditek Kelet-Erdélyben: őskörnyezet és porozitásfejlődés. — Földtani Közlöny 146/3, 257-274.

BEKE B. \& FODOR L. 2014: Deformációs szalagok porózus, szemcsés kőzetekben. — Földtani Közlöny 144/1, 255-274.

Beke, B., Fodor, L., Millar, L. \& Petrik, A. 2019: Deformation band formation as a function of progressive burial: Depth calibration 
and mechanism change in the Pannonian Basin (Hungary). — Marine and Petroleum Geology 105, 1-16., https://doi.org/10.1016/ j.marpetgeo.2019.04.006

Benedek, K., Nagy, Zs., Dunkl, I., Szabó, Cs. \& Józsa, S. 2001: Petrographical, geochemical and geochronological constraints on igneous clasts and sediments hosted in the Oligo-Miocene Bakony Molasse, Hungary: evidence for a Paleo-Drava River system. International Journal of Earth Sciences 90/3, 519-533., HTTPS://doi.org/10.1007/s005310000183

BÉRCZI I. 1969: Az algyői felsőpannóniai homokkőösszlet üledékföldtani vizsgálata. — Földtani Közlöny 99/4, 337-350.

BÉRCZI I. \& ViCZIÁN I. 1973: Üledékes kôzettani vizsgálatok a dél-alföldi neogénben. — Földtani Közlöny 103/3-4, 319-339.

BERÉNYI ÜVEges I., BERÉNYI ÜvEGes J. \& VID G. 2006: Adalékok a Baradla-barlang fejlődésének elméletéhez üledék vizsgálatok alapján. - Karszt és Barlang 2006/1-2,33-40.

BIDLó G. 1996: A talajásványtani vizsgálatok története a Budapesti Múszaki Egyetem Ásvány- és Földtani Tanszékén. — Agrokémia és Talajtan 45/3-4, 217-220.

BiDLÓ G. \& TöRÖK E. 1963: A Marcal hordalékának ásványtani vizsgálata. — Földtani Közlöny 93/2, 244-247.

Biró T., JózSA S., KARÁTSON D. \& SzENTHE I. 2013: A budai Mátyás-hegy bryozoás márga összletébe települt vulkanogén képződmény kôzettani-vulkanológiai vizsgálata. — Földtani Közlöny 143/3, 239-250.

BóDi B. 1938: A Budapest-környéki harmadkori kavicsok kőzettani vizsgálata, különös tekintettel a levantei kavicsképződményekre. — Földtani Közlöny 68/7-9, 180-207.

BODOR S. \& SZAKMÁNY Gy. 2009: A felső-permi Cserdi Konglomerátum Formáció kavicsanyagának kőzettani és geokémiai vizsgálati eredményei (XV. szerkezetkutató fúrás, Ny-Mecsek). — Földtani Közlöny 139/4, 325-340.

Bodor, S., Földessy, J., KRISTÁly, F. \& Zajzon, N. 2013: Diagenesis and ore forming processes in the Bódvaszilas Sandstone of the Rudabánya ore deposit, NE Hungary. - Carpathian Journal of Earth and Environmental Sciences 8/4, 147-153.

Bodor, S., SzAKMÁNy, Gy., JóZsA, S. \& Máthé, Z. 2012: Petrology and geochemistry of the Upper Permian - Middle Triassic siliciclastic formations of the Ibafa-4 borehole (NW Mecsek Mts., Hungary). — Carpathian Journal of Earth and Environmental Sciences 7/4, 219-230.

Bodrogi I. \& SzEnTPÉTeRY I. 2000: Felső-kréta kôzettípusok az alsó-miocén Szuhogyi Konglomerátumból (Észak-Magyarország, Rudabányai-hegység). — Földtani Közlöny 130/3, 423-450.

BogGs, S. JR. 2009: Petrology of Sedimentary Rocks. — Cambridge University Press, 600 p., https://doi.org/10.1017/CBO9780511626487

BöCKH J. 1872: Fóth-Gödöllő-Aszód környékének földtani viszonyai. — Földtani Közlöny 2/11, 6-18.

BradÁk, B., Kiss, K., Barta, B., VArga, GY., Szeberényi, J., Józsa, S., Novothny, Á., Kovács, J., Markó, A., Mészáros, E. \& Szalai, Z. 2013: Different paleoenvironments of the Pleistocene age identified in Veróce outcrop, Hungary: Preliminary results. Quaternary International 319, 199 136., https://doi.org/10.1016/j.quaint.2013.11.035

BREZSNYÁNSZKY K. \& HAAS J. 1984: A szenon Nekézsenyi Konglomerátum Formáció sztratotípus szelvényének szedimentológiai és tektonikai vizsgálata. — Földtani Közlöny 114, 81-100.

BuRJán B. 2002: A Pesti-síkság kavicsos üledékeinek szemcseeloszlási vizsgálata. — Földtani Közlöny 132, 161-173.

BURJÁN B. 2003: Budapest környéki idős Duna-teraszok nehézásvány-tartalmának cluster-analízis alapú statisztikai vizsgálata. — Földrajzi Értesítő 52/3-4, 171-185.

CsÁNK E-NÉ 1963: A Piliscsév 4. sz. fúrás oligocén képződményeinek üledékkőzettani vizsgálata. — MÁFI Évi Jelentése 1961-ról 1, 383-392.

CSÁNK E-NÉ \& SIPOSS Z. 1962: Andezitvulkánosság kőzetanyagának nyomai a középső-felsô-oligocén partszegélyi homokos összletben a Dorogi-medence DK-i részén. — MÁFI Évi Jelentése 1960-ról, 147-158.

CSAPÓ L. 1998: A Kisalföldi és a Gerecse-peremi Duna-teraszok nehézásvány vizsgálata. — Földtani Közlöny 128/2-3, 499-518.

CsÁszÁr G. 1995: A gerecsei és a vértes-előtéri kréta kutatás eredményeinek áttekintése. —Általános Földtani Szemle 27, $133-152$.

CsÁszÁR G. 2006: Kavics- és breccsabetelepülések a Vasasi Márga Formációban Zsibrik és Ófalu között. — MÁFI Évi Jelentése 2004röl, 205-213.

CsÁszÁR, G. \& ÁRGYELÁN, G. B. 1994: Stratigraphical and micromineralogical investigation of Lower Cretaceous sediments in Gerecse Mts. (Hungary). — Cretaceous Research 15/4, 417-434., https://doi.org/10.1006/cres.1994.1024

Császár G., Görög Á., Gyuricza Gy., Sieglné Farkas Á., Szente I. \& Szinger B. 2007: A Vasasi Márga földtani, őslénytani és üledékföldtani jellegei a Zsibrik és Ófalu közötti területen. — Földtani Közlöny 137/2, 193-226.

CsicsÁK J. \& SZAKMÁNY Gy. 1998: A Jakabhegyi Homokkő Formáció legfelsô, ,átmeneti” rétegei kőzettani-geokémiai vizsgálatának eredményei. - Földtani Közlöny 128/4, 535-553.

Csillag G., Fodor L., Sebe K., Müller P., Ruszkiczay-Rüdiger Zs., Thamóné Bozsó E. \& Bada G. 2010: A szélerózió szerepe a Dunántúl negyedidőszaki felszínfejlődésében. — Földtani Közlöny 140/4, 463-482.

DiCKINSON, W. R. 1970: Interpreting detrital modes of grauwacke and arkose. — Journal of Sedimentary Petrology 40/2, 695-707., https://doi.org/10.1306/74d72018-2b21-11d7-8648000102c1865d

DicKINSON, W. R. 1985: Interpreting provenance from detrital modes of sandstones. — In: ZuFFA, G. G. (ed.): Provenane of Arenites. NATO ASI series C 148, 333-361., https://doi.org/10.1007/978-94-017-2809-6

Dickinson, W. R. \& SuCZeK, C. 1979: Plate tectonics and sandstone compositions. - AAPG Bulletin 63/12, 2164-2182., https://doi.org/10.1306/2f9188fb-16ce-11d7-8645000102c1865d

Dомокоs, G. 2019: The Gömböc Pill. — The Mathematical Intelligencer 41/2, 9-11., https://doi.org/10.1007/s00283-019-09891-x

DuNKL I. 1990: A középhegységi eocén fedős bauxitok törmelékes cirkonkristályainak fission track kora: a korai eocén vulkanizmus bizonyítéka. —Általános Földtani Szemle 25, 163-177.

ELEK I. 1982: A Komádi alapfúrás mikromineralógiai vizsgálata. — MÁFI Évi Jelentése 1980-ról, 81-92.

ELEK I. 1987: Alföldi kutatófúrások mikromineralógiai feldolgozásából levonható következtetések. —MÁFI Évi Jelentése 1985-ról, 128-135. 
FARICS É. \& JózSA S. 2017: A Keleti-Bakony triász időszaki vulkanogén képződményeinek petrográfiai vizsgálata és képződési körülményeik értelmezése. — Földtani Közlöny 147/1, 25-38., https://doi.org/10.23928/foldt.kozl.2017.147.1.25

FARICS É., JóZSA S. \& HAAS J. 2015: A Budai-hegység felső-eocén összletének bázisán települő lávakőzet- és tufaklasztokat tartalmazó törmelékes üledékes kőzetek petrográfiai jellegei. — Földtani Közlöny 145/4, 331-350.

FARKAS A. K. 2013: A Vatyai Bronzkori Kultúra köeszközeinek archeometriai vizsgálata. — PhD értekezés, Debreceni Egyetem, 110 p.

FARKAS R. \& JÓZSA S. 2005: A Pisznicei-zsomboly üledékkitöltésének elemzése eredetvizsgálat és termális hatások céljából. —Gerecse Barlangkutató és Természetvédó Egyesület Évkönyve 2004, 29-36.

FARKAS-PETŐ, A. \& Horváth, T. 2014: Archaeometric database of archaeological stone tools (a suggestion for new data processing method). - Archeometriai Múhely 11/2, 103-113.-

Farkas-Pető, A., Horváth, T., Papp, I. \& Kovács-PÁlfFy, P. 2014: Archaeometric investigation of the stone tools of the Vatya culture (Pest county, Hungary). — Carpathian Journal of Earth and Environmental Sciences 9/1, 81-94.

FARKAS-SzŐKE Sz. 2008: Vértesszőlősi chopperek és chopping tool-ok technológiai elemzése. —Archeometriai Múhely 2008/2, 23-29.

FAZEKAS V. 1987: A mecseki perm és alsótriász korú törmelékes formációk ásványos összetétele. — Földtani Közlöny 117/1, 11-30.

FAZEKAS V. 1989: Ásvány-kőzettani megfigyelések a Jakabhegyi Homokkő Formáció DK-dunántúli előfordulásaiban. — Földtani Közlöny 119/4, 359-371.

FEKETE J. 2003: Felsó-oligocén és alsó-miocén glaukonitos képzódmények ásványtani vizsgálata. — Diplomamunka, ELTE Ásványtani Tanszék, Budapest, 128 p.

FEKETE Z. 1935: Adatok a hárshegyi homokkő geológiájához. — Földtani Közlöny 65/4-6, 126-150.

FoLK, R. L. 1956: The role of texture and composition in sandstone classification: DISCUSSION. — Journal of Sedimentary Petrology 26/2, 166-171., https://doi.org/10.1306/74d70506-2b21-11d7-8648000102c1865d

FöLDVÁRI M., LELKES Gy., VeTő I. \& VICZIÁN I. 1973: Kőzettani, ásványtani és geokémiai módszerek együttes alkalmazása tatabányai alsókréta fúrásminták vizsgálatára. — Földtani Közlöny 103/3-4, 364-371.

FRANYÓ F. 1963: A futóhomok és a lösz települési viszonyai a Duna-Tisza-köze középső részén. — MÁFI Évi Jelentés 1961-ról 2, 31-46.

FÜGEDI U., GyURICZA Gy. \& Tolmács D. 2015: Szemelvények a magyarországi területi geokémiai kutatásokból — történeti áttekintés. - Földtani Közlöny 145/3, 287-300.

FÜLÖP J. 1966: A Villányi-hegység krétaidőszaki képződményei. — Geologica Hungarica Series Geologica 15, 1-131.

FÜRI J. \& SzAKMÁNy Gy. 2004: A Miháldy-gyújtemény csiszolt kőeszközeinek nyersanyagtípusai. — In: ILON G. (szerk.): Óskoros Kutatók III. Összejövetelének konferenciakötete: Halottkultuszés temetkezés. $\mathrm{M} \Omega \mathrm{M} \Omega \Sigma$, III, Szombathely-Bozsok, 2002. október $7-$ 9. Szombathely, Magyarország, Vas Megyei Múzeumok Igazgatósága, 461-472.

GÁl B., Poros Zs. \& Molnár F. 2008: A Hárshegyi Homokkő Formáció hidrotermális kifejlődései és azok kapcsolatai regionális földtani eseményekhez. — Földtani Közlöny 138/1, 49-60.

GECSE É. T. 1982: A nagyegyházi bauxittelep mikromineralógiai vizsgálata. —MÁFI Évi Jelentése 1980-ról, 435-448.

GEDEONNÉ RAJETZKY M. 1973a: A mindszenti és csongrádi kutatófúrások mikromineralógiai vizsgálata különös tekintettel az anyagszállítás egykori irányaira. - MÁFI Évi Jelentése 1971-ról, 169-184.

GEDEONNÉ RAJETZKY M. 1973b: Fosszilis folyóvízi üledékek mikromineralógiai spektrumának értelmezése recens hordalékvizsgálatok alapján. - Földtani Közlöny 103/3-4, 285-293.

GedeONNÉ RAJETZKY M. 1976: Pliocénvégi-negyedkori üledékciklusok mikromineralógiai spektruma a Szarvas-I. sz. fúrásban. — MÁFI Évi Jelentése 1974-ról, 172-183.

Goncalves, C. C. \& Braga, P. F. A. 2019: Heavy Mineral Sands in Brazil: Deposits, Characteristics, and Extraction Potential of Selected Areas. - Minerals 9/3 (176), 1-15., https://doi.org/10.3390/min9030176

GulYÁs-Kis, Cs. 2003: Upper Carboniferous flora from the Mecsek Mts (Southern Hungary) — summarized results. - Acta Geologica Hungarica 46/1, 115-125., https://doi.org/10.1556/AGeol.46.2003.1.8

GYALOG L. \& BUDAI T. 2004: Javaslatok Magyarország földtani képződményeinek litosztratigráfiai tagolására. — MÁFI Évi Jelentése 2002-ról, 195-232.

GYŐRFI É. 2015: Új adatok a Dráva-medencei középső-miocén konglomerátum-breccsa kőzettani összetételéről és lehordási területéről - Földtani Közlöny 145/1, 23-44.

Győri, O., HaAs, J., Hips, K., Lukoczki, G., Budai, T., Demény, A. \& Szócs, E. 2020: Dolomitization of shallow-water, mixed siliciclastic-carbonate sequences: The Lower Triassic ramp succession of the Transdanubian Range, Hungary. - Sedimentary Geology 395, 20 p., https://doi.org/10.1016/j.sedgeo.2019.105549

GyuRICZA Gy. \& SÁSDI L. 2009: A Baradla-barlangrendszer kialakulásának kérdései a tágabb környezet földtani fejlődésének tükrében. — Földtani Közlöny 139/1, 83-92.

HaAs J. 1984: Oligocén-alsó-miocén. — In: HaAs J., J. Edelényi E., Gidai L., Kaiser M., Kretzoi M. \& Oravecz J. 1984: Sümeg és környékének földtani felépítése. Geologica Hungarica Series Geologica 20, 190-193.

HAJós M. 1954: A kővágóörsi Alsókőhát és Nyárvölgy kvarchomokkő üveg- és öntödei-homok elfordulása. — Földtani Közlöny 84/4, 356-361.

HÁmOR G. 1970: A kelet-mecseki miocén. - MÁFI Évkönyve 53/1, 1-371.

HARTIKAINEN, A., HoRVÁTH, I., ÓdOR, L., Ó. KovÁCS, L. \& CSONGRÁDI, J. 1992: Regional multimedia geochemical exploration for Au in the Tokaj Mountains, northeast Hungary. — Applied Geochemistry 7, 533-545., https://doi.org/10.1016/0883-2927(92)90069-f

Herrmann M. 1954a: Bükkalji pannóniai homokvizsgálatok. — Földtani Közlöny 84/4, 338-349.

HERRMANN M. 1954b: A mezókeresztesi elsố sekélyfúrás homokjainak mikromineralógiája. — Annales Historico-naturales Musei Nationalis Hungarici 46/5, 7-14.

HERRMANN M. 1955: Mátrai és cserhátaljai pannon homokok vizsgálata. —Annales Historico-naturales Musei Nationalis Hungarici 47/6, 7-14. 
Herrmann M. 1956a: A várpalotai Szabó-bánya miocén homokrétegeinek nehézásványai. - Annales Historico-naturales Musei Nationalis Hungarici 48/7, 207-210.

HERRMANN M. 1956b: Kisalföldi és dunántúli pannóniai homok mikromineralógiai vizsgálata. — Földtani Közlöny 86/1, 59-66.

HofMANn K. 1871: A buda-nagykovácsi hegység földtani viszonyai. — Magyar Királyi Földtani Intézet Évkönyve 1, 199-273.

HoFMANN K. 1879: Jelentés az 1878 nyarán Szilágymegye keleti részében tett földtani részletes felvételekről. — Földtani Közlöny 9/5_ 6, 167-212.

HoRvÁTH A. 1988: Adatok a magyaregregyi bádeni durvatörmelékes összlet magmatit kavicsainak kőzettani-geokémiai ismeretéhez; kapcsolatuk a kurdi fúrások magmatitjaival. — Földtani Közlöny 118/3, 251-264.

HoRvÁtH T. 2013: Budakalász M0/12. kora bronzkori lelőhely kőanyaga. Archeometriai Múhely 10/2, 141-176.

HorvátH, E. \& TARI, G. 1987: Middle triassic volcanism in the Buda Mountains. - Annales Universitas Scientiarum Budapestinensis de Rolando Eötvös Nominatae 27, 16 p.

Horváth E., GÁbris Gy. \& Juvigné E. 1992: Egy pleisztocén vezérszint a Kárpát-medencében: a Bag Tefra. — Földtani Közlöny 122/24, 233-249.

HorvÁTH, P., KovÁCS, G. \& SZAKMÁNY, Gy. 2003: Eclogite and garnet amphibolite pebbles from Miocene conglomerates (Pannonian Basin, Hungary): implications for the Variscan metamorphic evolution of the Tisza Megaunit. — Geologica Carpathica 54/6, 355-366.

HoRvÁth, P., JóZSA, S. \& SZAKMÁNY, Gy. 2005: Petrography and geochemistry of eclogite pebbles from pleistocene conglomerates at Dunavarsány, Hungary. - Abstract of 7th International Eclogite Conference, 3-9 July 2005, Seggau, Austria, Mitteilungen der Österreichischen Mineralogischen Gesellschaft 150, p. 54.

Hum L. 2002: Délkelet-dunántúli löszösszletek ásványos és geokémiai jellegei és ezek eredete. — Földtani Közlöny 132/különszám, $117-132$.

INGERSOLL, R. V. 1990: Actualistic sandstone petrofacies: Discriminating modern and ancient source rocks. — Geology 18/8, 733-736., https://doi.org/10.1130/0091-7613(1990)018<0733:ASPDMA>2.3.CO;2

INKEY B. 1914: A magyarországi talajvizsgálat története. — A Magyar Királyi Földtani Intézet kiadványa, Budapest, 54 p.

JAKUCS L. 1953: A békebarlang felfedezése. — Mûvelt Nép Könyvkiadó, Budapest, 144 p.

JÁMBOR Á. 1969: Karbon képzôdmények a Mecsek és a Villányi-hegység közötti területen. — MÁFI Évi Jelentése 1967-ról, 215-221.

JÁMBOR, Á. 1992: Pleistocene ventifact occurrences in Hungary. — Acta Geologica Hungarica 35/4, 407-436.

JÁMBOR Á. 2002: A magyarországi pleisztocén éleskavics előfordulások és földtani jelentőségük. — Földtani Közlöny 132/különszám, $101-116$.

JÁMBOR Á. 2010: Hömpölyök — óriás kavicsok — előfordulása a hazai pleisztocén folyóvízi képződményekben. — Földrajzi Közlemények 134/2, 159-171.

JÁMBOR Á. \& KoRPÁs L. 1971: A Dunántúli-középhegység kavicsképződményeinek rétegtani helyzete. — MÁFIÉvi Jelentése 1969-ról, 75-92.

JÁMBOR Á. \& SzABÓ J. 1961: Mecsek-hegységi miocén kavicsvizsgálatok földtani eredményei. — Földtani Közlöny 91/3, 316-324.

Józsa S., SZAKMÁNy Gy., MÁTHÉ Z. \& BARABÁs A. 2009: A Mecsek és környéke miocén konglomerátum összletek felszíni elterjedése és a kavicsanyag összetétele. - In: M. TóтH T. (szerk.): Magmás és metamorf képzódmények a Tiszai Egységben. GeoLitera, Szeged, 195-217.

JuHÁsz Á. 1962: A balatonfelvidéki permi homokkőösszlet kvarcporfiranyagának eredete. — Földtani Közlöny 92/2, 160-173.

JuhÁsz, A. 1999: Diagenetic constraints on Paleohydrodynamic and Thermal Reconstruction of Neogene Sediments at the Békés Basin - Battonya High Hydrocarbon Province, SE Hungary. - PhD dissertation, University of Bern, Switzerland, $154 \mathrm{p}$.

JuhÁsz, A., M. TÓTH, T., RAMSEYER, K. \& MATTER, A. 2002: Connected fluid evolution in fractured crystalline basement and overlying sediments, Pannonian Basin, SE Hungary. — Chemical Geology 182/2-4, 91-120., https://doi.org/10.1016/S0009-2541(01)00269-8

JuHÁsz Gy. \& THAMóNÉ Bozsó E. 2006: Az alföldi pannóniai s.l. képződmények ásványi összetétele II. — A pannóniai s.l. homokok és homokkövek ásványi összetétel változásának tendenciái és földtani jelentőségük. — Földtani Közlöny 136/2, 431-450.

Kaczanowska, M., KozŁowski, J.K., Drobniewicz, B. \& Wasilewski, M. 2011. Lithic implements from Maroslele-Pana. - In: PALuch, T. (ed.): Maroslele-Pana. Egy középsőneolitikus lelőhely a kultúrák határvidékén. Móra Ferenc Múzeum, Szeged, 275-291.

KALMÁR J. \& ViCZE M. 2006: A szigetszentmiklósi bronzkori temető kőzetanyagának alaktani és petrográfiai vizsgálata. — Földtani Közlöny 136/1, 105-119.

Kalmár J., Kuti L., Kovács-Pálffy P. \& Szendreiné Korén E. 1997: Ásványtani és szedimentológiai vizsgálatok a Szarvasimintaterület felszíni-felszín-közeli képződményein. — Földtani Közlöny 127/3-4, 385-403.

KASZANITZKY F. 1956: Az alsóoligocén (hárshegyi) homokkő ásvány-kőzettani vizsgálata. — Földtani Közlöny 86/3, 244-256.

Kelemen, P., Dunkl, I., Csillag, G., Mindszenty, A., von Eynatten, H. \& Józsa, S. 2017: Tracing multiple resedimentation on an isolated karstified plateau: The bauxite-bearing Miocene red clay of the Southern Bakony Mountains, Hungary. - Sedimentary Geology 358, 84-96. http://dx.doi.org/10.1016/j.sedgeo.2017.07.005

KesszLer H. 1942: Az északbihari forrásbarlangok. Beszámoló a M. Kir. Földtani Intézet vitaüléseinek munkálatairól. — A Magyar Királyi Földtani Intézet évi jelentésének függeléke 4/7, 39-51.

KIRÁLY Cs. 2017: Mihályi-Répcelak természetes $\mathrm{CO}_{2}$ elôfordulás környezetgeokémiai vizsgálata. — PhD értekezés, ELTE TTK Környezettudományi Doktori Iskola, Budapest, 163 p.

Király, Cs., Falus, Gy., Gresina, F., Jakab, G., Szalai, Z. \& Varga, Gy. 2019: Granulometric properties of particles in Upper Miocene sandstones from thin sections, Szolnok Formation, Hungary. — Hungarian Geographical Bulletin 68/4, 341-353., https://doi.org /10.15201/hungeobull.68.4.2

KIsS, J. 1952: La constitution minéralogique de la bauxite de Nézsa. — Acta Geologica 1/1-4, 113-132.

KIss J. 1958: A darnóhegyi neogén üledékkőzettani vizsgálata. — Földtani Közlöny 88/1, 27-41.

KLEB B. 1968: A Mecsek-hegység déli előtere pannóniai képződményeinek üledékföldtani vizsgálata. — Földtani Közlöny 98/3-4, 335-359. Косн A. 1871: A Szt.-Endre-Vissegradi és a Pilis hegység földtani leírása. — Magyar Királyi Földtani Intézet Évkönyve 1/2, $143-198$. 
Kосн A. 1874: Adatok Kolozsvár vidéke földtani képződményeinek pontosabb ismeretéhez. — Földtani Közlöny 4/10-11, 251-283.

Konrád, Gy., Sebe, K., Halász, A. \& Babinszki, E. 2010: Sedimentology of a Permian playa lake: the Boda Claystone Formation, Hungary. — Geologos 16/1, 27-41., https://doi.org/10.2478/v10118-010-0002-1

Kordos L. 1976: Jelentés a Dokumentációs Szakosztály 1976. évi munkájáról. in: Beszámoló a Magyar Karszt- és Barlangkutató Társulat 1976. évi tevékenységéról. — Magyar Karszt- és Barlangkutató Társulat, Budapest, 72-275.

KoRPÁs L. 1981: A Dunántúli-középhegység oligocén - alsó-miocén képződményei. — MÁFI Évkönyv 64, 149 p.

KöRMENDY R. 2015: 2014. évi hordalékkutatások a Visegrádi-hegységben. — Lelóhely 2015/2, 2-17.

KöRmÖs, S., SteInBACH, G. \& SchUbert, F. 2019a: Fluid inclusion chemostratigraphy on the Eocene Kosd Formation (Central Hungary). - XXVth European Current Research on Fluid Inclusions, Abstracts, p. 66.

Körmös, S., Varga, A., Radovics, B. G. \& Schubert, F. 2019b: Diagenetic evolution of the sandstone member of Kosd Formation (Central Hungary). - European Geosciences Union General Assembly 2019, Paper: EGU2019-15470

KRIVÁN P. 1973: A periglaciális Dunaüledékek közelhegységi törmelékanyagának eredete a Dunakanyartól a Pesti-síkságig. —Földtani Közlöny 103/2, 136-144.

KuTI L., Tóth T., KALMÁR J. \& KovÁCs-PÁLFFy P. 2003: Szikes talajok ásványi összetétele és recens ásványképződés Apajpusztán és Zabszék térségében. - Agrokémia és Talajtan 52/3-4, 275-292.

KÜRTHY D., SZAKMÁNY GY., JóZSA S. \& SZABÓ G. 2013: A regölyi kora vaskori sírhalom kőzetleleteinek előzetes archeometriai vizsgálati eredményei. - Archeometriai Múhely 10/2,111-125.

LEÉL-Őssy Sz. 2011: A Budai Vár-barlang és környezetének földtani viszonyai. — In: A Budai Vár-barlangra vonatkozó tudományos és történeti ismeretek összegzése. A Duna-Ipoly Nemzeti Park Igazgatóság és a Budavári Önkormányzat megbízásából készítette a DIR Kft, Budapest, 5-50.

LENGYEL E. 1930: Alföldi homokfajták ásványos összetétele. — Földtani Közlöny 60/1-12, 67-75.

LENGYEL E. 1931: Szeged-környéki homokfajták összehasonlító kőzettani vizsgálata. — A Szegedi Alföldkutató Bizottság Könyvtára, VII. szakosztály közleményei 2, 1-106.

Magyar, L., Benei, B. \& Halász, A. 2016: Re-evaluation of archive pebble distribution data for the Upper Permian Bakonya Sandstone Member of the Kővágószőlős Formation, Hungary — a comparison with the composition of cores BAF-1 and BAF-1A. — Földtani Közlöny 146/3, 223-232.

MARKó, A. \& KÁZMÉr, M. 2004: The use of nummulitic chert in the Middle Palaeolithic in Hungary. — In: FülöP, É. \& CSEH, J. (eds.): „Die aktuellen Fragen des Mittelpaläolithikums in Mitteleuropa”. „Topical issues of the research of Middle Palaeolithic period in Central Europe”. Tudományos Füzetek, Tata 12, 53-62.

MáthÉZ. \& VARGA A. 2012: „Ízesítő” a permi Bodai Agyagkő Formáció őskörnyezeti rekonstrukciójához: kősó utáni pszeudomorfózák a BAT-4 fúrás agyagkőmintáiban. — Földtani Közlöny 142/2, 201-204.

MÁTYÁs, J. 1994: Diagenesis and porosity evolution of Neogene reservoir sandstones in the Pannonian Basin (Southeast Hungary). — $\mathrm{PhD}$ dissertation, University of Bern, Switzerland, $196 \mathrm{p}$.

MÁtYÁs, J. \& MatTer, A. 1997: Diagenetic indicators of meteoric flow in the Pannonian Basin, southeastern Hungary. — In: MontANEZ, I. P., GregG, J. M. \& Shelton, K. L. (eds.): Basin-Wide Diagenetic Patterns: Integrated Petrologic, Geochemical, and Hydrologic Considerations. Society for Economic Paleontologists and Mineralogists, Special Publication 57, 281-296.

MCBRIDE, E. F. 1963: A classification of common sandstones. — Journal of Sedimentary Petrology 33/3, 664-669., HTTPS://doi.org/ 10.1306/74d70ee8-2b21-11d7-8648000102c1865d

MiKLós D. G. 2018: A Nyugat-Mecsek (Borjúsréti-völgy) kora-miocén rétegsorának komplex petrográfiai vizsgálata. —Diplomamunka, ELTE-TTK, Kőzettan-Geokémiai Tanszék, Budapest, 137 p.

MikLós D. G. \& JózsA S. 2017: Törmelékes összletek komplex petrográfiai vizsgálata a Borjúsréti-völgy (Nyugat-Mecsek) miocén kavicsos rétegsorának példáján. — In: DÉGI J., KirÁly E., Kónya P., KovÁcs I. J., PÁl-MolnÁr E., ThamónÉ Bozsó E., TÖRÖK K. \& UdVARDi B. (szerk.): Ahol az elemek találkoznak: víz, föld és túz határán. 8. Kőzettani és Geokémiai Vándorgyúlés kiadványa, Szihalom, 2017. szeptember 7-9., 113-114.

MikLós D. G., Józsa S. \& SzAKMÁNy Gy. 2018: Törmelékes rétegsorok komplex eredetvizsgálata (KEVi). Ötelemes, összehangolt törmelékeskőzet-elemző vizsgálatsor. — Földtani Közlöny 148/4, 355-366., https://doi.org/10.23928/foldt.kozl.2018.148.4.355

MikLós D. G., SzAKMÁNy Gy., JózSA S., HoRVÁth F. \& STARnini, E. 2019: Vörös homokkő anyagú szerszámkövek petrográfiai vizsgálati eredményei a Hódmezővásárhely-Gorzsa késő-neolit tell település példáján. — In: PÁL-Molnár E., H. LuKÁCS R. HARANGI Sz., Szemerédi M., Németh B., MolnáR K. \& JANKovics M. É. (szerk.): Saxa Loquuntur - Kóbe zárt történetek. 10. Kőzettani és Geokémiai Vándorgyűlés kiadványa, Mátraháza, 2019. szeptember 5-7., 60-63.

Mindszenty, A., Gál-Sólymos, K., Csordás-Tóth, A., Imre, I., Felvári, Gy., W. Ruttner, A., Böröczky, T. \& Knauer, J. 1991: Extraclasts from Cretaceous/Tertiary Bauxites of the Transdanubian Central Range and the Northern Calcareous Alps. Preliminary Results and Tentative Geological Interpretation. - In: LoBITZER, H. \& CsÁsZÁr, G. (eds.): Jubiläumsschrift 20 Jahre Geologische Zusammenarbeit Österreich - Ungarn 1, 309-345.

MolnáR B. 1961: A Duna-Tisza közi eolikus rétegek felszíni és felszín alatti kiterjedése. — Földtani Közlöny 65/7-9, 300-315.

MoLNÁR B. 1963: A délalföldi pliocén és pleisztocén üledékek tagolódása nehézásvány-összetétel alapján. — Földtani Közlöny 93/1,97-107.

MolNÁr B. 1964: A magyarországi folyók homoküledékeinek nehézásvány-összetétel vizsgálata. — Hidrológiai Közlöny 91/3, 347-355.

MolNáR B. 1966: Pliocén és pleisztocén lehordási területváltozások az Alföldön. — Földtani Közlöny 96/4, 404-413.

MolNÁr B. 1973: Az Alföld harmadidőszak-végi és negyedkori feltöltődési ciklusai. — Földtani Közlöny 103/3-4, $294-310$.

NÁdor A., Thamóné Bozsó E., Magyari Á., BABINSZKi E., DudKó A. \& Tóth Z. 2007a: Neotektonika és klímaváltozás együttes hatása a Körös-medence késô-pleisztocén vízhálózat-fejlődésére. —MÁFI Évi Jelentése 2005-ról, 131-148.

NÁdor, A., ThamónÉ Bozsó, E., MAGYARI, Á. \& BABInsZKi, E. 2007b: Fluvial responses to tectonics and climate change during the Late 
Weichselian in the eastern part of the Pannonian Basin (Hungary). — Sedimentary Geology 202, 174-192., https://doi.org/10.1016/ J.SEDGEO.2007.03.001

NosZKY J. 1935: Budapest környékének helvétien rétegei. — Földtani Közlöny 65/7-9, 163-182.

ORAVECZ J. 1965: Szilur kőzetkavicsok földtörténeti szerepe törmelékes összleteinkben. — Földtani Közlöny 95/4, 401-405.

Palágyi, Sz., Csirke, O., Futó, J., Hlavay, J., Raucsik, B., SZAbó, A. \& VASSÁNyI, I. 2006: Mining data from Roman sandstone quarries. —Acta Archaeologica Academiae Scientarium Hungaricae 57, 395-422., https://doi.org/10.1556/AArch.57.2006.4.5

PANTó D. 1935: A dunai arany mosás kérdése. — Földtani Közlöny 65/7-9, 182-274.

PAPP F. \& SEMPTEY F. 1956: Nehézásvány vizsgálatok két ózdi mélyfúrás anyagában. — Bányászati Lapok 89/8, 485-492.

PAPP K. 1899: Éles-kavicsok (dreikanterek) Magyarország hajdani pusztáin (steppéin). — Földtani Közlöny 29/5-7, 135-147.

PÉCSI-DonÁth, É. 1985: On the mineralogical and petrological properties of the younger loess in Hungary. — In: PÉCSI M. (ed.): Loess and the Quaternary. Chinese and Hungarian Case Studies. Studies in geography in Hungary (18), Akadémiai Kiadó, Budapest, 93-104.

PÉCSINÉ DonÁTH É. 1958: Duna-terasz kavicsok görgetettségi vizsgálata. — Földtani Közlöny 88/1, 57-75.

PÉTERDI B. 2004: Bronzkori és vaskori öntőformák petrográfiai vizsgálata. — In: ILON G. (szerk.): Óskoros Kutatók III. Összejövetelének konferenciakötete: Halottkultusz és temetkezés. M $\Omega \mathrm{M} \Omega \Sigma$, III, Szombathely-Bozsok, 2002. október 7-9. Szombathely, Magyarország, Vas Megyei Múzeumok Igazgatósága, 487-525.

PÉTERDI B. 2012: Balatonőszöd-Temetői dúlô rézkori lelőhely homokkő nyersanyagú kőeszközeinek kôzettani és geokémiai vizsgálata. - Archeometriai Múhely 9/4, 265-285.

PÉTERdi, B., KovÁcs, T., SzAKMÁnY, Gy. \& T. Biró K. 2005: Petrographic Investigation of Bronze and Iron Age Casting Moulds from the Collection of the Hungarian National Museum. - Geoarchaeological and Bioarchaeological Studies 3, 87-90.

Pettijohn, F. J. 1954: Classification of Sandstones. — The Journal of Geology 62/4, 360-365., https://doi.org/10.1086/626172

Pettijohn, F. J., Potter, P. E. \& Siever, R. 1972: Sand and Sandstone. — Springer-Verlag, New York, 618 p., https://doi.org/10.1126/ science.178.4060.497

Philippe, M., SZAKmány, Gy., Gulyás-Kis, Cs. \& JózSA, S. 2000: An Upper Carboniferous-Lower Permian silicified wood in the Miocene conglomerate from the western Mecsek Mts. (southern Hungary). — Neues Jahrbuch für Geologie und Paläontologie Monatshefte 2000/4, 193-204., https://doi.org/10.1127/njgpm/2000/2000/193

PIros L. 2010: Homokkő nyersanyagú köeszközzök, szerszámkövek archeometriai vizsgálata Gorzsa (DK-Magyarország). — Diplomamunka, ELTE Kőzettan-Geokémiai Tanszék, 65 p.

Piros O. \& GyURICZA Gy. 1986: A Baradla-barlang eróziós-genetikai vizsgálata. — NME Közleményei, Miskolc, I. Sorozat, Bányászat 33/1-4, 47-55.

PolacseK Zs. \& BA J. 2017: Tatabányai barlangkutatás. — Barlangkutatás 2017, kutatási jelentések, barlangi kutatásvezetők válogatott kutatási jelentései 2017. évből. Tatabánya, 184 p.

PolgÁRI M. 1982: A Maros- és a Körös-hordalék gránátjainak pásztázó elektronmikroszkópos vizsgálata a hordalékkúpok kijelölése céljából. — Földtani Közlöny 112/2, 143-160.

Pozsgai, E., Józsa, S., Dunkl, I., Sebe, K., Thamó-Bozsó, E., SAJó, I., Dezsó, J. \& von Eynatten, H. 2017: Provenance of the Upper Triassic siliciclastics of the Mecsek Mountains and Villány Hills (Pannonian Basin, Hungary): constraints to the Early Mesozoic paleogeography of the Tisza Megaunit. — International Journal of Earth Sciences 106/6, 2005-2024., https://doi.org/10.1007/ s00531-016-1406-0

RAdovics B. G., KöRMÖs, S. \& SchUBERT, F. 2017: A magyar paleogén medence szénhidrogén rendszere, és eocén tárolóinak kihívása hatástanulmány. — In: DéGi J., Király E., Kónya P., Kovács I. J., PÁl-Molnár E., Thamóné Bozsó E., TöröK K. \& Udvardi B. (szerk.): Ahol az elemek találkoznak: víz, föld és tüz határán. 8. Kőzettani és Geokémiai Vándorgyúlés kiadványa, Szihalom, 2017, szeptember 7-9., 147-149.

RÁKóczY S. 1905: A Muraköz és a Győr melletti Dunaszakasz aranyfövénye, összefüggésben a Tauern havas aranyteléreivel. — Bányászati és Kohászati Lapok 38/1-9, 537-553.

RAVASZNÉ BARANYAI L. 1973: A kelet-mecseki miocén képződmények ásvány-kőzettani vizsgálata. — MÁFI Évkönyv 53/2, 485-741.

Rотн L. 1879: A rákos-ruszti hegyvonulat és a Lajta-hegység déli részének geológiai vázlata. — Földtani Közlöny 9/3-4, 99-110.

Rотн S. 1885: A Magas-Tátra déli oldalának hajdani jégárairól. — Földtani Közlöny 15/1-2, 9-31.

SAllay M. \& ThamónÉ Bozsó E. 1988: A magyarországi harmad- és negyedidőszaki üledékes képződmények mikromineralógiai vizsgálati helyzete. —MÁFI Évi Jelentése 1986-ról, 435-439.

SÁRKÖZINÉ FARKAS E. 1966: Csolnok-Ebszőny környéki eocén képződmények üledékkőzettani vizsgálata. — MÁFI Évi Jelentése 1964 röl, 321-328.

SÁSDI L. 2003: Újabb földtani adatok a gerecsei édesvízi mészkövek keletkezéséhez. — Karsztfejlődés 8, 129-143.

SCHAFARZIK F. 1901: A Szapáryfalvi diluviáliskoru babérczes agyagról. — Földtani Közlöny 31/1-4, 28-34.

SCHUller, V. \& FrISCH, W. 2006: Heavy mineral provenance and paleocurrent data of the Upper Cretaceous Gosau succession of the Apuseni Mountains (Romania). — Geologica Carpathica 57/1, 29-39.

Schuller, V., Frisch, W., DANišík, M., DunKL, I. \& Melinte, M.C. 2009: Upper Cretaceous Gosau deposits of the Apuseni Mountains (Romania) - similarities and differences to the Eastern Alps. — Austrian Journal of Earth Sciences 102/1, 133-145.

SENDULA E. 2015: Ipari CO tárolásra alkalmas hazai üledékes kốzetek petrográfiai vizsgálata és a rendszerekben várható geokémiai változások modellezése. - Diplomamunka, ELTE Kôzettan-Geokémiai Tanszék, Budapest, 95 p.

Sinkó Zs. 2014: A kompakciós folyamatok vizsgálata a Szolnoki Formációban (Hódmezôvásárhely-I fúrás, Makói-árok). — Diplomamunka, SZTE Ásványtani, Geokémiai és Kőzettani Tanszék, 72 p.

Soós I. \& JÁMBOR Á. 1960: Növénymaradványos felsőkarbon kavicsok a Mecsek hegységi helvéti kavicsösszletből. — Földtani Közlöny 90/4, 456-458. 
SpránITZ T., VÁczi B., LANGE T. P. \& JózSA S. 2017: Jégszállította dumortierites gneisz, klinohumitos márvány és szkapolitos amfibolit a Duna pleisztocén kavicsanyagában. — Földtani Közlöny 147/3, 311-326., https://doi.org/10.23928/foldt.kozl.2017.147.3.311

Starnini, E., Szakmány, Gy., Józsa, S., Kasztovszky, Zs., Szilágyi, V., Maróti, B., VoyteK, B. \& Horváth, F. 2015: Lithics from the Tell Site Hódmezővásárhely-Gorzsa (Southeast Hungary): Typology, Technology, Use and Raw Material Strategies during the Late Neolithic (Tisza Culture). - In: Hansen, S., Raczky, P., Anders, A. \& Reinburger, A. (eds.): Neolithic and Copper Age between the Carpathians and the Aegean Sea; Chronologies and Technologies from the $6^{\text {th }}$ to the $4^{\text {th }}$ Millennium BCE. Archäologie in Eurasien 31, 105-128. ISBN: 978-3-7749-3972-1

STEFANOVITS P. 1952: Andezittufán kialakult talajok a Börzsöny hegységben. — Agrokémia és Talajtan 1/3, 309-320.

STRAUSz L. 1949: A Dunántúl ÉNy-i részének kavicsképződményei. — Földtani Közlöny 79/1-4, 8-68.

StraUSz L. 1952: Kavics-tanulmányok a Dunántúl középső részéből. — Földtani Közlöny 82/4-6, 119-136.

SZABÓ I. \& VINCE J. 2002: Bükk hegységi törmelékes perm képződmények földtani, kőzettani vázlata és ércindikációi. — Földtani Közlöny 132/2, 181-221.

SzABó J. 1858: Pest-Buda környékének földtani leírása. — A Magyar Tudományos Akadémia által Nagy-Károly-Díjjal koszorúzott pályairat, Magyar Tudományos Akadémia, Pest, 63 p.

SzABó J. 1861: Geológiai viszonyok és talajnemek ismertetése I. füzet. Békés és Csanádmegye. — A Magyar Gazdasági Egyesület kiadása, Pest, 150 p.

SzABó J. 1872: Egy morena képződmény a Mátrában. — Földtani Közlöny 2, 233-241.

SzABó P. 1955: A Duna-Tisza közi felsô-pleisztocén homok rétegek származása ásványos összetétel alapján. — Földtani Közlöny 85/4, $442-456$.

Szaвó, T. \& Domokos, G. 2010: A new classification system for pebble and crystal shapes based on static equilibrium points. —Central Europian Geology 53/1, 1-19., https://doi.org/10.1556/CEuGeol.53.2010.1.1

SzÁDECZKY K. Gy. 1932: A helvetien transgressió konglomerátja és sarmatien kavicsok Kolozsvár környékén. — Az Erdélyi Múzeumegyesület Természettudományi Szakosztályának Közleményei 36, 25-39.

SZÁDECZKY-KARDOSs, E. 1933: Die Bestimmung des abrollungs gardes. — Zentralblatt für Mineralogie, Geologie und Palaontologie, Abteilung B, 389-401.

SZÁDECZKY-KARDOSS E. 1939: A Gerecse-hegység magas terraszairól. — Földtani Közlöny 69/10-12, 279-290.

SZAKMÁNY, Gy. 1996: Results of the petrographical analysis of some samples of the ground and polished stone assemblage. - In: MakKay, J., Starnini, E. \& TuloK, M. (szerk.): Excavations at Bicske-Galagonyás (part III). The Notenkopf and Sopot-Bicske cultural phases. Società per la Preistoria e Protostoria della Regione Friuli-Venezia Giulia, Quaderno 6, 224-241.

SzAKMÁnY, Gy. \& JózsA, S. 1994: Rare pebbles from the Miocene Conglomerate of Mecsek Mts., Hungary. — Acta MineralogicaPetrographica, Szeged 35, 53-64.

SZAKMÁNY Gy. \& NAGY B. 2005: Balatonlelle - Felső-Gamász lelőhelyrôl elôkerült késô rézkori vörös homokkő ôrlőkövek petrográfiai vizsgálatának eredményei. - Archeometriai Múhely 2/3, 13-21

SzAKMÁny Gy., StARnini E., Horváth F. \& Bradák B. 2008: Gorzsa késô neolit tell településrôl előkerült kôeszközök archeometriai vizsgálatának előzetes eredményei (Tisza kultúra, DK Magyarország). — Archeometriai Múhely 5/3, 13-26.

SZAKMÁny, Gy., Starnini, E., Horváth, F., SZILÁGyi, V. \& KAsZTovszKY, Zs. 2009: Investigating trade and exchange patterns during the Late Neolithic: first results of the archaeometric analyses of the raw materials for the polished and ground stone tools from Tell Gorzsa (SE Hungary). — In: ILon, G. (szerk.): Őskoros Kutatók VI. Összejövetelének Konferenciakötete: Nyersanyagok és Kereskedelem. Kőszeg, 2009. március 19-21. M $\Omega$ M $\Omega$, VI, Szombathely, 363-377.

Szakmány, Gy., Starnini, E., Horváth, F. \& BRAdÁK, B. 2011: Investigating Trade and Exchange Patterns in Prehistory: Preliminary Results of the Archaeometric Analyses of Stone Artefacts from Tell Gorzsa (South-East Hungary). — In: TurbanTi-MEMmI, I. (ed.): Proceedings of the $37^{\text {th }}$ International Symposium on Archaeometry, $12^{\text {th }}-16^{\text {th }}$ May 2008, Siena, Italy, Springer-Verlag Berlin Heidelberg, 311-319.

Szeberényi J., Józsa S., Alžbeta M., Juraj H., Balogh J., Fábián SZ. A., Kiss E. \& Varga GY. 2014: Dunateraszok helyzete a Visegrádi-szorosban. - VII. Magyar Földrajzi Konferencia kiadványa, Miskolc, 513-527.

SZEBERÉNYi J., JóZSA S., SimON I., KisS K., BRADÁK B. \& VicZiáN I. 2015: A Visegrádi-szoros kiemelt helyzetú kavicsos üledékeinek vizsgálata Zebegény térségében, és jelentősége a magas dunai teraszok morfosztratigráfiai besorolásakor. — Földtani Közlöny 145/4, 367-383.

SZENDREI G. 1970: Kiskunsági talajok ellenálló ásványainak vizsgálata mikroszkóppal. — Agrokémia és Talajtan 19/1-2, $137-146$.

SZENDREI G. 1994: Talajásványtan. — Módszertani Közlemények 14/1, 217 p.

SzENTES Gy. 1963: A bódvaszilasi Meteor-barlang környékének kőzetföldtani viszonyai. — Karszt és Barlang 1963/2, 61-65.

SZENTPÉTERY I. 1988: A Rudabányai-hegység és környezetének oligocén, alsó-miocén képzőódményei. — MÁFI Évi Jelentése 1986-ról, $121-128$.

SzŐCS, E. \& HIPS, K. 2018: Multiphase carbonate cementation in the Miocene Pétervására Sandstone (North Hungary): implications for basinal fluid flow and burial history. — Geologica Carpathica 69/6, 515-527., https://doi.org/10.1515/geoca-2018-0030

Sző́cs E., HIPS K., JózsA S. \& BENDő Zs. 2015: A kora-miocén Pétervásárai Homokkő diagenezis-története. — Földtani Közlöny 145/4, 351-366.

SzTANÓ O. 1990: Durvatörmelékes üledékek gravitációs tömegmozgásai egy gerecsei alsókréta tengeralatti csatornakitöltố konglomerátum példáján. - Általános Földtani Szemle 25, 337-360.

SZTANó, O. \& JóZSA, S. 1996: Interaction of basin-margin faults and tidal currents on nearshore sedimentary architecture and composition: a case study from the Early Miocene of northern Hungary. - Tectonophysics 266/1-4, 319-341., https://doi.org/10.1016/ S0040-1951(96)00196-5 
SZTRÓKAY K. I. 1932: A budai márga kőzettani vizsgálata. — Földtani Közlöny 62/1-12, 81-121.

SzTRÓKAY K. I. 1952: Mecseki vasércképződés. - Az MTA Közleményei 5/1-2, 211-230.

Szujó G. L., Sebe K., Sipos Gy. \& PozsGai E. 2017: Pleisztocén folyóvízi kavics a Villányi-hegységben. — Földtani Közlöny 147/1, 85-98.

T. Biró K., JózSa S., J. Szabó K. \& M. Virág Zs. 2013: Duna: A nagy szállítószalag. — Archeometriai Múhely 10/1, 33-49.

T. BIRó K. 1992: Adatok a korai baltakészítés technológiájához. — Acta Musei Papensis /Pápai Múzeumi Értesító 3-4, 33-79.

TaRi, G., Dövényi, P., Dunkl, I., Horváth, F., Lenkey, L., Stefanescu, M., SzAFí́n, P. \& Tóth, T. 1999: Lithospheric structure of the Pannonian basin derived from seismic, gravity and geothermal data. — In: Durand, B., Jolivet, L., Horváth, F. \& SÉranne, M. (eds): The Mediterranean Basins: Tertiary Extension within the Alpine Orogen. Geological Society, London, Special Publications 156, 215-250., https://doi.org/10.1144/gsl.sp.1999.156.01.12

THAMÓNÉ Bozsó E. 1985: A fehérvárcsurgói kvarchomok telep ásvány-kőzettani vizsgálatának eredményei. — MÁFI Évi Jelentése 1983ról, 75-80.

THAMóNÉ Bozsó E. 1991: A magyarországi kainozóos homokok és homokkövek nehézásvány-tartalmának mennyiségi viszonyai. — MÁFI Évi Jelentése 1989-ról, 587-595.

THAMÓ-Bozsó, E. 1993: A petrographic classification of Cenozoic sands and sandstones in Hungary. — MÁFI Évi Jelentése 1991-ról, $275-287$.

THAMÓNÉ Bozsó E. 2002a: A mikromineralógiai vizsgálati módszer hazai alkalmazásának áttekintése. II. Függelék, Mikromineralógia. — In: PAPP G.: A magyar topografikus és leíró ásványtan története. Topographia Mineralogica Hungariae 7, 351-352.

THAMóNÉ Bozsó E. 2002b: Magyarországi kainozoos homokok és homokkövek ásványi alkotói és származásuk meghatározásának lehetősége. - MÁFI Évi Jelentése 1997-1998-ról, 119-134.

THAmó-Bozsó, E. \& Ó. KovÁcs, L. 2007: Evolution of Quaternary to modern fluvial network in the Mid-Hungarian Plain, indicated by heavy mineral distributions and statistical analysis of heavy mineral data. — In: Mange, M. A. \& Wright, D. T. (eds): Heavy minerals in use. Developments in Sedimentology 58, 491-514., https://doi.org/10.1016/s0070-4571(07)58019-2

THAMÓNÉ Bozsó E., JuHÁsz Gy. \& Ó. Kovács L. 2006: Az alföldi pannóniai s.l. képződmények ásványi összetétele I. A pannóniai s.l. homokok és homokkövek jellemzői és eredete. - Földtani Közlöny 136/2, 407-430.

Thamó-Bozsó, E., Murray, A. S., NÁdor, A., Magyari, Á. \& Babinszki, E. 2007: Investigation of river network evolution using luminescence dating and heavy mineral analysis of Late-Quaternary fluvial sands from the Great Hungarian Plain. — Quaternary Geochronology 2/1-4, 168-173., https://doi.org/10.1016/j.quageo.2006.05.012

Thamóné Bozsó E., Csillag G., KáKay-Szabó O., Kónya P., Király E. \& Müller P. M. 2012: Szél által polírozott pleisztocén kőzetfelszínek vizsgálati eredményei a Dunántúli-középhegységből. — MÁFI Évi Jelentése 2010-ról, 41-53.

Thamó-Bozsó, E., Ó. KovÁcs, L., Magyari, Á. \& Marsi, I. 2014: Tracing the origin of loess in Hungary with the help of heavy mineral composition data. — Quaternary International 319, 11-21., https://doi.org/10.1016/j.quaint.2013.04.030

Tóth F., VARGA A. \& RAucsiK B. 2013: Agyagásványtani és petrográfiai vizsgálatok új szemléletú értelmezése a Makói-árok túlnyomásos zónáiból (Endrődi Formáció, Pannon-medence, Magyarország). — In: KovÁcs A. (szerk.): XV. Székelyföldi Geológus Találkozó kiadványa. Kézdivásárhely, Románia, 74-75.

TöRÖK Á. 2008: Építészeti kőanyagok előfordulása és felhasználása a mai Magyarország területén a XVIII. századig. —- In: SzAKÁLL, S. (szerk): Az ásványok és az ember a mai Magyarország területén a XVIII. század végéig. Fókuszban az ásványi anyag. A Miskolci Egyetem Közleménye, A sorozat, Bányászat 74, Miskolc, Egyetemi Kiadó 137-155.

VADÁsz E. 1935: A Mecsek hegység. — Magyar Tájak Földtani Leírása I, 180 p.

VADÁsz E. 1940: Mágnesvaskő előfordulás a Mecsekhegységben. — Bányászati és Kohászati Lapok 73/12, p. 210.

VARGA, A. \& RAUCSIK, B. 2014: Pedogenic calcrete records in southern Transdanubia, Hungary: A brief review with paleoenvironmental and paleogeographic implications. — Central European Geology 57/2, 137-151., https://doi.org/10.1556/CEuGeol.57.2014.2.2

VARGA A., SZAKMÁNY GY., JóZSA S. \& MÁTHÉZZ. 2001: A nyugat-mecseki alsó-miocén konglomerátum karbon homokkő kavicsainak és a Tésenyi Homokkő Formáció képződményeinek petrográfiai és geokémiai összehasonlítása. — Földtani Közlöny 131/1-2, 11-36.

Varga A., Szakmány Gy., Raucsik B., Kedves M. \& Józsa S. 2002: Eocén calcrete kavicsok a nyugat-mecseki miocén konglomerátumból. — Földtani Közlöny 132/1, 57-82.

VARGA A., SZAKMÁNY GY., JóZSA S. \& MÁTHÉ Z. 2003: Petrology and geochemistry of Upper Carboniferous siliciclastic rocks (Téseny Sandstone Formation) from the Slavonian-Drava Unit (Tisza Megaunit, S Hungary) — summarized results. — Acta Geologica Hungarica 46/1, 95-113., https://doi.org/10.1556/AGeol.46.2003.1.7

VARGA A., RAUCSIK B. \& SZAKMÁNY Gy. 2004: A Siklósbodony Sb-1 mélyfúrás feltételezett karbon-perm határképződményeinek ásványtani, kőzettani és geokémiai jellemzői. — Földtani Közlöny 134/3, 321-343.

VARGa A., RAUCSIK B., SZAKMÁNy Gy. \& MáthÉZ. 2006: A Bodai Aleurolit Formáció törmelékes kőzettípusainak ásványtani, kőzettani és geokémiai jellemzői. - Földtani Közlöny 136/6, 201-232.

Varga, A., Szakmány, Gy., Árgyelán, T., Józsa, S., Raucsik, B. \& Máthé, Z. 2007: Complex examination of the Upper Paleozoic siliciclastic rocks from southern Transdanubia, SW Hungary - Mineralogical, petrographic, and geochemical study. — In: ARRIBAS, J., Critelli, S. \& Johnsson, M. J. (eds.): Sedimentary Provenance and Petrogenesis: Perspectives from Petrography and Geochemistry. Boulder, Geological Society of America, 221-240., https://doi.org/10.1130/2006.2420(14)

VARGa A., Raucsik B., KovÁcs Kis V. \& SZAKMÁNy Gy. 2008: A felsô-paleozoikumi Turonyi Formáció (Szlavóniai-Drávai-terrénum) pelites kőzeteinek ásványtani és kőzettani jellemzői. — Földtani Közlöny 138/1, 5-20.

VARGa A., Mikes T. \& RaucsiK B. 2009: A mecseki toarci feketepala Réka-völgyi szelvényének előzetes petrográfiai és nehézásványvizsgálati eredményei. — Földtani Közlöny 139/1,33-54.

VARGA A., ÚJVÁRI G. \& KovÁCS J. 2012a: Cirkon egykristály U-Pb korok a danitzpusztai pannóniai homokból: közvetett bizonyítékok az aljzatot alkotó metamorfitok kevert prevariszkuszi protolitjaira. — Földtani Közlöny 142/1, 95-98. 
Varga, A., RaucsiK, B. \& Bajnóczi, B. 2012b: Nodular calcrete from the Lower Permian Korpád Sandstone Formation (borehole Dinnyeberki 9015, Mecsek Mts, Hungary) and its palaeoenvironmental significance. — Földtani Közlöny 142/4, 375-378.

VArga A., Raucsik B. \& Szakmány Gy. 2014: Az alsó-permi Korpádi Homokkő Formáció törmelékes kőzeteinek ásványtani és kőzettani jellemzői a Túrony-1 fúrásban (Szlavóniai-Drávai-terrénum). — Földtani Közlöny 144/4, 211-230., https://doi.org/ 10.23928/foldt.kozl.2014.144.3.211-230

Varga A., Pál-Molnár E., Raucsik B., Schubert F., Garaguly I., Lukács R. \& Kiss B. 2015a: A dél-alföldi permo-mezozoos képződmények: a diagenezis-történet jellemzése és előzetes regionális korreláció kőzettani és geokémiai eredmények alapján. — In: DÁlyay V. \& SÁmson M. (szerk.): Tisia Konferencia. Pécs, Molnár Nyomda és Kiadó, 17-20.

Varga A., Raucsik B., Schubert F., Garaguly I., Mészáros E., Fiser-Nagy Á. \& Dabi G. 2015b: A Szegedi-medence és közvetlen környezetének diagenezis-történet és mikrotektonikai vizsgálata: Ásotthalom-Mórahalom mintaterület (Projektszám: HK7315. 28.41/95). — Kutatási jelentés, SZTE Ásványtani, Geokémiai és Kôzettani Tanszék, Szeged, 118 p.

Varga A., Baranyi V., RaucsiK B. \& Schubert F. 2017: Az Endrődi Formáció kőzettani és palinológiai vizsgálata a Hódmezóvásárhely-I fúrásban (Makói-árok) — őskörnyezeti és diagenezis-történeti értékelés. — Földtani Közlöny 147/1, 61-84., https://doi.org/10.23928/foldt.kozl.2017.147.1.61

Varga, A., Bozsó, G., Garaguly, I., Raucsik, B., Bencsik, A. \& Kóbor, B. 2019: Cements, Waters, and Scales: An Integrated Study of the Szeged Geothermal Systems (SE Hungary) to Characterize Natural Environmental Conditions of the Thermal Aquifer. Geofluids 2019, Paper 4863814, 21 p., https://doi.org/10.1155/2019/4863814

VARRÓK K. 1954: A nyugatbakonyi mediterrán kavicstakaró anyaga, eredete és kora. — MÁFI Évi Jelentése 1952-ról, 189-193.

VASKóNÉ DÁVID K. 1988: Kromit vizsgálatok és azok jelentősége a Tatabányai-medence és a vértes elôterének alsó- és középsôkrétájában. - MÁFI Évi Jelentése 1986-ról, 241-261.

VÉGH S. 1956: Üledékes kôzettani vizsgálatok Hidas-Váralja környékén. — Földtani Közlöny 86/2,151-160.

Velledits F., Lein R., Krystyn L., Péró Cs., Piros O. \& BlaU J. 2017: A Reiflingi esemény hatása az Északi-Mészkőalpok és az Aggteleki-hegység középső-triász fejlődésére. — Földtani Közlöny 147/1, 3-24., https://doi.org/10.23928/foldt.kozl.2017.147.1.3

VeNDL A. 1913: A Csepel sziget homokjáról. — Földtani Közlöny 43/7-9, 331-343.

VENDL A. 1932: A kiscelli agyag. —MÁFI Évkönyv 29/2,97-152.

VerEs Zs. \& VARGA A. in press: Karbonátos konkréciók az alsó-miocén Pétervásárai Homokkő Formációban (Pétervásárai-dombság, Leleszi-völgy): genetikai megfontolások morfológiai és petrográfiai vizsgálatok eredményei alapján. — Földtani Közlöny

VID G. (szerk.) 2007: Vid Gábor és társai által 2006-ban végzett barlangkutató tevékenység. — Kézirat, Cholnoky Jenő Karszt- és barlangkutatási pályázat, egyéni kategória. 25 p.

VID G. 2012: Beszámoló a 2011. évben a Baradla- és a Béke-barlangokban végzett barlangkutató tevékenységről. — Kézirat, 20 p.

VÖRÖs I. 1958: Iszkaszentgyörgyi bauxit-szelvények mikromineralógiai és nyomelem vizsgálata. — Földtani Közlöny 88/1, 48-56.

WÉBER B. 1964 Újabb növénymaradványos felsőkarbon kavicsok a Ny-i Mecsek helvéti rétegeiből. — Földtani Közlöny 94/3, 379-381.

Worden, R. H. \& Burley, S. D. 2003: Sandstone diagenesis: the evolution of sand to stone. — In: Burley S. D. \& Worden R. H. (eds.): Sandstone diagenesis: Recent and Ancient. Blackwell Publishing, Oxford, 3-44., https://doi.org/10.1002/9781444304459.ch

ZajZon, N., SzABÓ, Zs. \& WeIsZburg, T. G. 2011: Multiple provenance of detrital zircons from the Permian-Triassic boundary in the Bükk Mts., Hungary. — International Journal of Earth Sciences 100/1, 125-138., https://doi.org/10.1007/s00531-009-0500-y

ZENTAY T. 1989: A Duna-Tisza köze déli részének agrogeológiái értékelése. —Módszertani Közlemények 13/2, 112 p.

Zuffa, G. 1980: Hybrid arenites: their composition and classification. - Journal of Sedimentary Petrology 50/1, 21-29., https://doi.org/10.1306/212f7950-2b24-11d7-8648000102c1865d

Zsemle, F., TöröK, K., Józsa, S. \& KázMÉr, M. 2001: Granulite pebbles from the Upper Pleistocene terrace of the Danube at Délegyháza, Hungary. - Földtani Közlöny 131/3-4, 461-474.

1., https://www.glossary.oilfield.slb.com/en/Terms/s/siliciclastic_sediment.aspx

2., https://foldtan.hu/sites/default/files/GEODALOK_2014_01_26.pdf

Kézirat beérkezett: 2020. 03. 30. 